\title{
DNA Methylation Suppression by Bhendi Yellow Vein Mosaic Virus
}

\author{
Kandhalu Sagadevan Dinesh Babu ${ }^{1}$, Ashirbad Guria ${ }^{1}$, Jeyalakshmi Karanthamalai ${ }^{1}$ (D), \\ Nagesh Srikakulam 1 (D), Kamlesh Kumari 1,2, Priyanka Sharma 1,3, Sam Aldrin Chandran 1,4, \\ Anburaj Daniel Barnabas ${ }^{5}$, Jebasingh Tennyson 6 (D) and Gopal Pandi ${ }^{1, *}$ (D) \\ 1 Department of Plant Biotechnology, School of Biotechnology, Madurai Kamaraj University, \\ Madurai 625021, India; ksdineshbabumku@gmail.com (K.S.D.B.); ashir.biotech@gmail.com (A.G.); \\ jeyasweety92@gmail.com (J.K.); bioinagesh@gmail.com (N.S.); kamlesh.kumari407@gmail.com (K.K.); \\ prnksharma862@gmail.com (P.S.); aldrin84@gmail.com (S.A.C.) \\ 2 Department of Plant Molecular Biology, University of Delhi, South Campus, New Delhi 110021, India \\ 3 Department of Genetic Engineering, School of Biotechnology, Madurai Kamaraj University, \\ Madurai 625021, India \\ 4 School of Chemical and Biotechnology, SASTRA University, Thanjavur 613401, India \\ 5 Department of Botany, The American College, Madurai 625002, India; adbarnabas@gmail.com \\ 6 Department of Plant Sciences, School of Biological Sciences, Madurai Kamaraj University, \\ Madurai 625021, India; jebasinghs@gmail.com \\ * Correspondence: pgopal.biotech@mkuniversity.org; Tel.: +91-452-2458230
}

Received: 3 May 2018; Accepted: 29 May 2018; Published: 31 May 2018

\begin{abstract}
Bhendi yellow vein mosaic virus (BYVMV) belongs to the monopartite begomovirus associated with the $\beta$ satellite. As a single-stranded DNA (ssDNA) virus, it should be amenable to transcriptional and post-transcriptional gene silencing (TGS and PTGS). Previously, we had demonstrated C2, C4 and $\beta C 1$ to be having different levels of influence on PTGS. Hence in the present study, a series of experiments such as agroinfiltration, chop-polymerase chain reaction (PCR), quantitative PCR (qPCR) and bisulfite next generation sequencing (NGS) were designed to analyse the involvement of BYVMV proteins on DNA methylation suppression. From the preliminary studies, we concluded that BYVMV genes were responsible for TGS suppression and C2, C4 genes from BYVMV were selected for further studies. Agroinfiltration experiments with mutant $C 2$ and $C 4$ partial tandem repeat (PTR) constructs of BYVMV have confirmed the role of C2 and C4 in DNA methylation impairment. The protoplast replication assay has shown that $C 4$ was not an impediment for viral DNA replication and subsequent agroinfiltration studies with the C4 mutant BYVMV PTR construct have revealed the involvement of C4 in viral DNA movement.
\end{abstract}

Keywords: begomovirus; DNA methylation; transcriptional gene silencing; suppressors; movement protein; bhendi yellow vein mosaic virus; bisulfite sequencing; next generation sequencing

\section{Introduction}

Geminiviruses are circular single-stranded DNA (ssDNA) viruses with twinned icosahedral particles that infect economically important plants and cause devastating effects on crop yield. Based on the genome organization, host range and vector, recently geminiviruses has been classified into nine genera Becurtovirus, Curtovirus, Grablovirus, Mastrevirus, Turncurtovirus, Topocuvirus, Capulavirus, Eragrovirus and Begomovirus [1]. Among these, the whitefly (Bemisia tabasi) transmitted begomovirus that infects dicot plants, is a diverse genus comprising of more than 288 species with either monopartite or bipartite genome [2]. Begomoviruses depend entirely on the host cellular machinery for their DNA replication, transcription, and translation $[3,4]$. They replicate via rolling circle replication (RCR) that 
happens through the formation of the double-stranded DNA replicative form (RF). The intermediate $\mathrm{RF}$ is converted into a minichromosome using host proteins, which then serves as a template for viral DNA replication and bicistronic transcription [5].

RNA silencing of invaded viruses is mediated by the host small interfering RNAs (siRNAs) at post-transcriptional level $[3,6]$ or at the chromatin level by histone/DNA modifications known as transcriptional gene silencing (TGS). Geminivirus minichromosomes succumb to TGS at chromatin level, either by the epigenetic modification of histone or by the methylation of DNA [7]. The addition of the methyl group to cytosine residues in the viral promoter is a stable modification that hinders viral DNA replication and transcription [8,9]. The pattern of DNA methylation is conserved across the plant kingdom which is constantly maintained by the domain rearranged DNA methyltransferases (DRM1), methyltransferases 1 (MET1) and Chromomethylases [10-12]; these enzymes methylate $\mathrm{CG}, \mathrm{CHG}$ and $\mathrm{CHH}$ sites, respectively. DNA methylation on promoter sequences prevents active gene transcription [13,14]. It has been established that $\mathrm{AC} 1, \mathrm{AC} 2 / \mathrm{C} 2$ and $\mathrm{V} 2$ of begomovirus and $\beta C 1$ of $\beta$ satellite have the capacity to interfere with the DNA methylation cycle by affecting the methylation pathway proteins either directly or indirectly. These results suggest the suppression of methylation-mediated gene silencing by begomoviral proteins [15-18].

Bhendi yellow vein mosaic virus (BYVMV) is a monopartite begomovirus, associated with a $\beta$ satellite molecule (Figure 1E,F). BYVMV is needed for DNA replication, encapsidation and viral movement, while $\beta$ satellite is essential for high accumulation of viral DNA and the expression of typical symptoms $[19,20]$. Apart from the $\beta C 1$, BYVMV C2 and $C 4$ also have a varying degree of post-transcriptional gene silencing (PTGS) suppressor activity [21,22]. Mutation on BYVMV C2 drastically reduces viral DNA accumulation, which hints at a possible role of C2 in viral DNA replication [23]. To understand the suppression of TGS by BYVMV, the present work has been carried out.Analyses of C4 and C2 mutations by the high depth bisulfite next generation sequencing (NGS) revealed that both genes interfere with the DNA methylation. Intriguingly, plants co-infiltrated the with partial tandem repeat construct of C4 mutant BYVMV (C4MAPTR, refer Section 4.1) and $\beta P T R$ (GenBank ID: AJ308425.1) remained asymptomatic. Further, studies on the protoplast and emerging leaf revealed that $\mathrm{C} 4$ has been involved in virus movement.

\section{Results}

\subsection{BYVMV Interferes with DNA Methylation}

It is well known that BYVMV is having $\mathrm{C} 2, \mathrm{C} 4$ and $\beta C 1$ as suppressors with varying degrees of PTGS suppression [22]. $C 4$ and $\beta C 1$ are also symptom determinants [24-27]. To understand BYVMV interference in the TGS pathway, we infiltrated pCAMBIAAPTR9 along with pBIN $\beta$ PTR4 (hereafter referred to as APTR and $\beta$ PTR) (GenBank ID: AF241479.1 and AJ308425.1) into N. benthamiana plants and the infiltrated plants showed severe leaf curling at 21 days of post-infiltration (dpi). Polymerase Chain Reaction (PCR) screened plants were subjected to GPCR (Quantitative PCR) and Southern hybridization to assure the BYVMV high accumulation as we demonstrated previously (Figure 1) [22,23]. The viral DNA isolated from 13 N. benthamiana plants co-infiltrated with APTR and $\beta$ PTR was digested with MSREs (Methylation-Sensitive Restriction Enzymes) such as Sau3AI, MboI and HpaII for chop-PCR. The MSRE's digested viral DNA sample was used for chop-PCR using primers of intergenic region (IR) (Table 1, Primers 1 and 2), V2 (Table 1, Primers 3 and 4), C2 (Table 1, Primers 5 and 6), C4 (Table 1, Primers 7 and 8), $\beta C 1$ (Table 1, Primers 9 and 10) and its upstream region (Table 1, Primers 11 and 12). The result showed a prominent reduction in amplification at least in one among the three enzymes (Supplementary Figure S1) when compared to undigested product. Intriguingly, complete reduction was observed with the $\mathrm{C} 4$ forward and V2 reverse primers which lie between the $\mathrm{C} 4$ and V2 genes yielding a $1.1 \mathrm{~kb}$ product (Supplementary Figure S1B). To substantiate chop-PCR results, we performed qPCR to precisely estimate the copy number on digested viral DNA using BYVMV or a $\beta$ satellite-specific primer and found over $90 \%$ reduction in HpaII or MboI digestion, 
respectively. In addition, the other two enzymes also showed $>50 \%$ reduction of amplification when quantified using BYVMV or $\beta$ satellite-specific primers, suggesting most of the viral DNA remains unmethylated (Figure 2A,B). In chop-PCR and subsequent qPCR, we observed an amplification of viral DNA sequences with the MSRE digested samples. This is because the efficiency of chop-PCR depends on the availability of an MSRE site within the amplicon, enzyme activity and the presence of methylated DNA, which is mediated by the initial response of $N$. benthamiana. Chop-PCR and qPCR roughly reveal that BYVMV is impairing the DNA methylation.

In order to examine the methylation level of the viral DNA precisely and accurately, we preferred the bisulfite method followed by the NGS (next generation sequencing). Though there are different methods available for DNA methylation analysis, bisulfite sequencing is considered as a "gold standard" for single base resolution measurement of DNA methylation. Bisulfite coupled with the NGS method gives greater advantages over the conventional method of methylation analysis. DNA methylation analysis by conventional bisulfite conversion, cloning and sequencing of an individual clone is a long, time-consuming process whereby interpretation of the DNA methylation level is carried out by analysing 10 to 20 clones corresponding to the specific genomic loci. In contrast to this, the bisulfite-NGS method gives the greater advantage of analysing methylation levels at whole genome level.

A
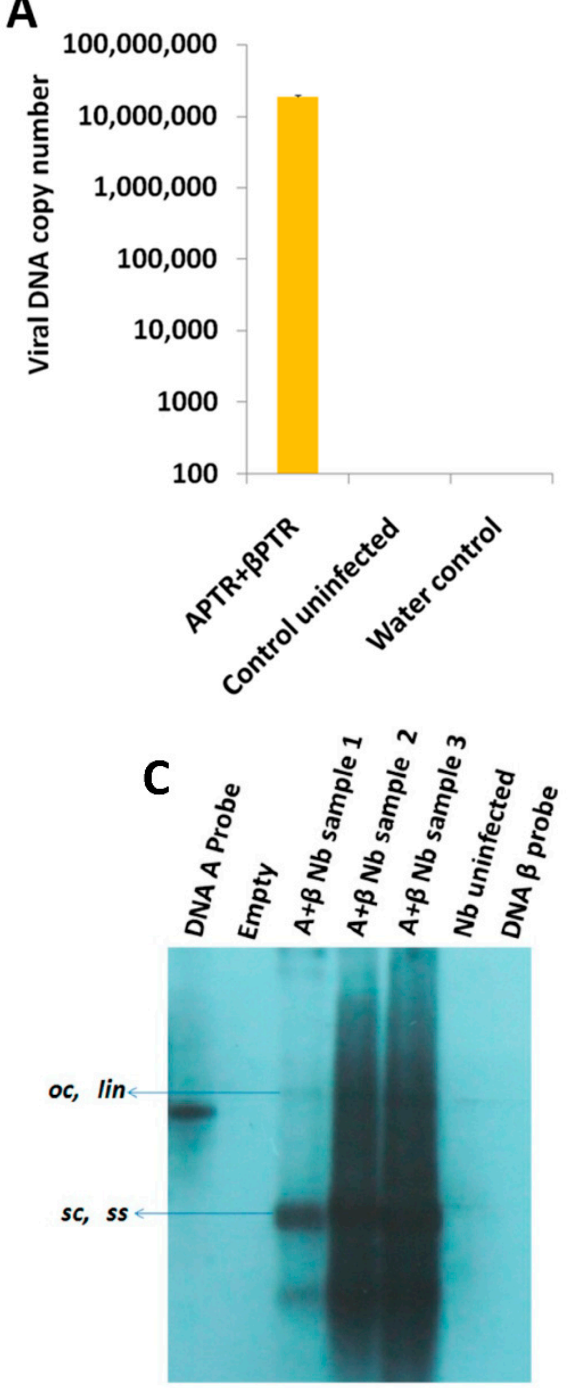

B
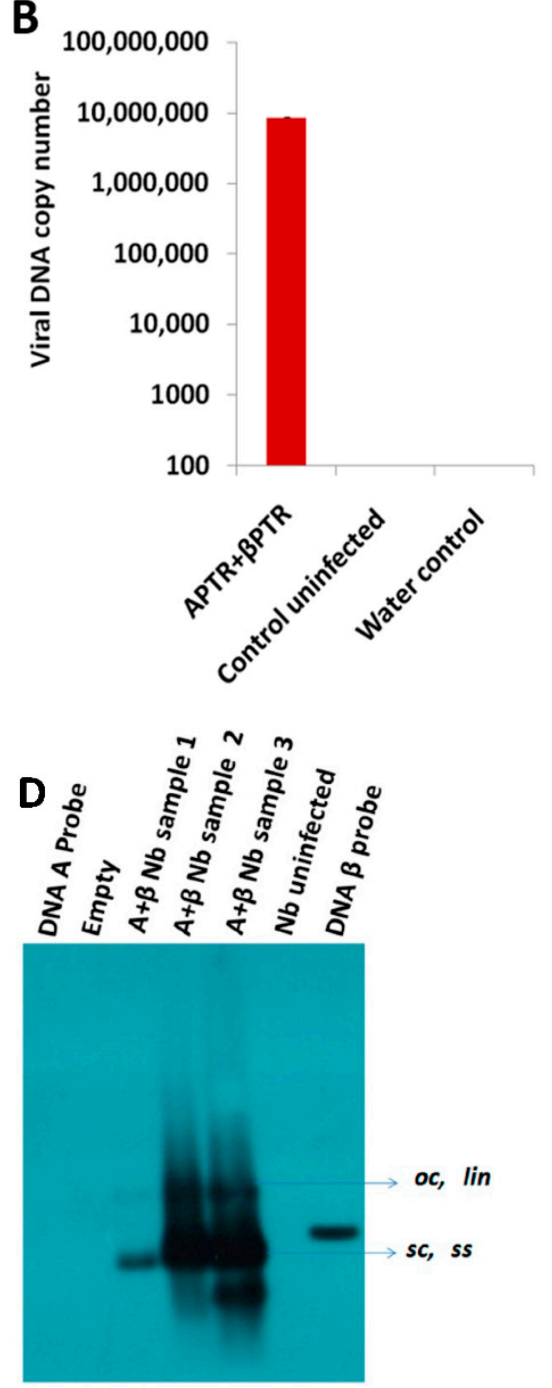

Figure 1. Cont. 

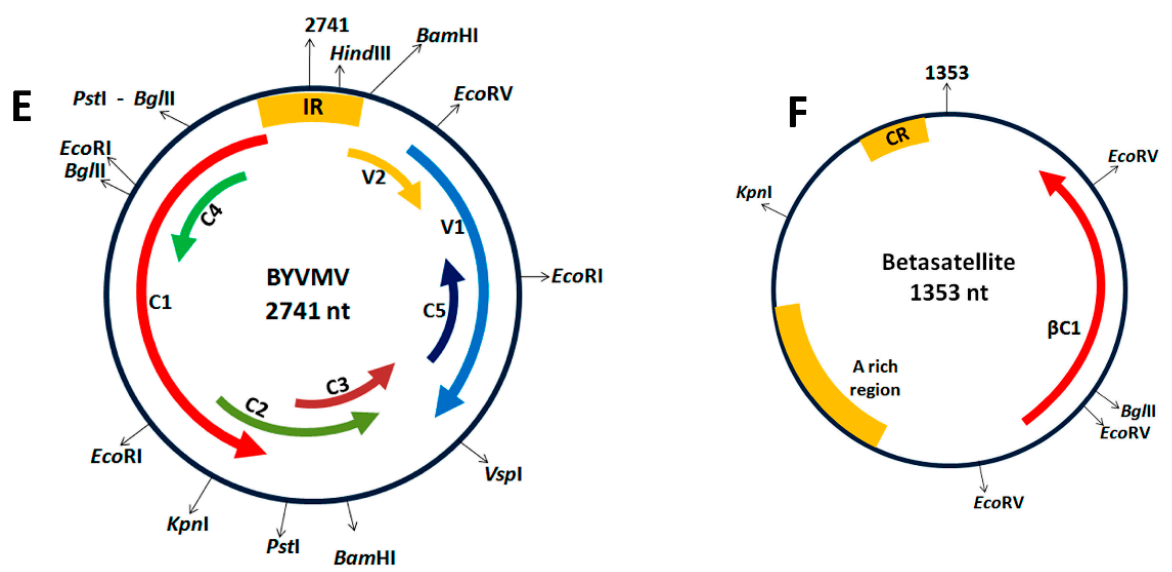

Figure 1. $q P C R$ (quantitative PCR) to detect the copy number. Quantitative PCR was performed using $50 \mathrm{ng}$ of viral DNA from APTR along with $\beta$ PTR-infiltrated $N$. benthamiana plants using (A) BYVMV-specific primer (B) $\beta$ satellite-specific primer. Southern confirmation of BYVMV accumulation with $5 \mu \mathrm{g}$ of isolated viral DNA (C) using DNA A and (D) $\beta$ satellite probe. Genome organization of Bhendi Yellow Vein Mosaic Virus (BYVMV) (GenBank: AF241479.1) (E) and associated $\beta$ satellite (GenBank: AJ308425.1) (F). (oc-open circular, lin-linear, sc—super coiled, ss—single stranded, $\mathrm{Nb}-\mathrm{N}$. benthamiana, $\mathrm{A}+\beta-\mathrm{APTR}+\beta \mathrm{PTR}, \mathrm{IR}$-intergenic region, $\mathrm{CR}$ - conserved region, nt-nucleotides).

A

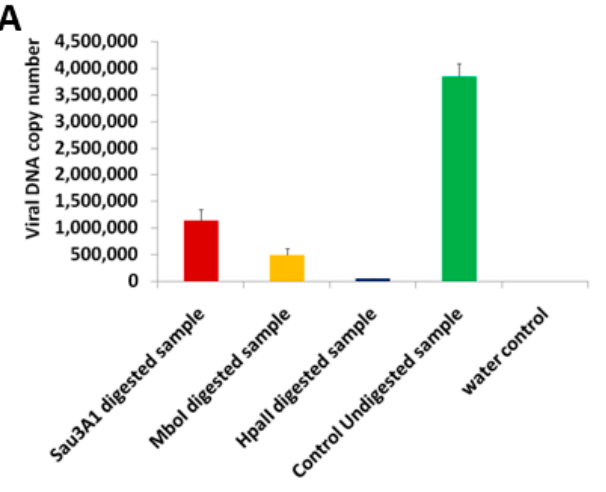

C

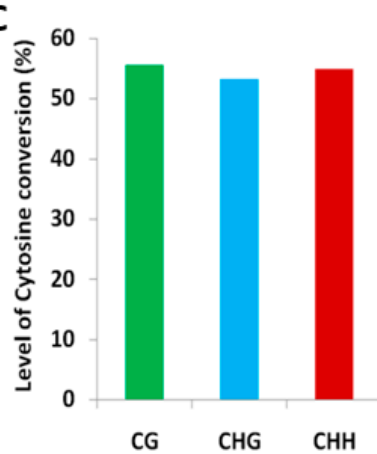

B
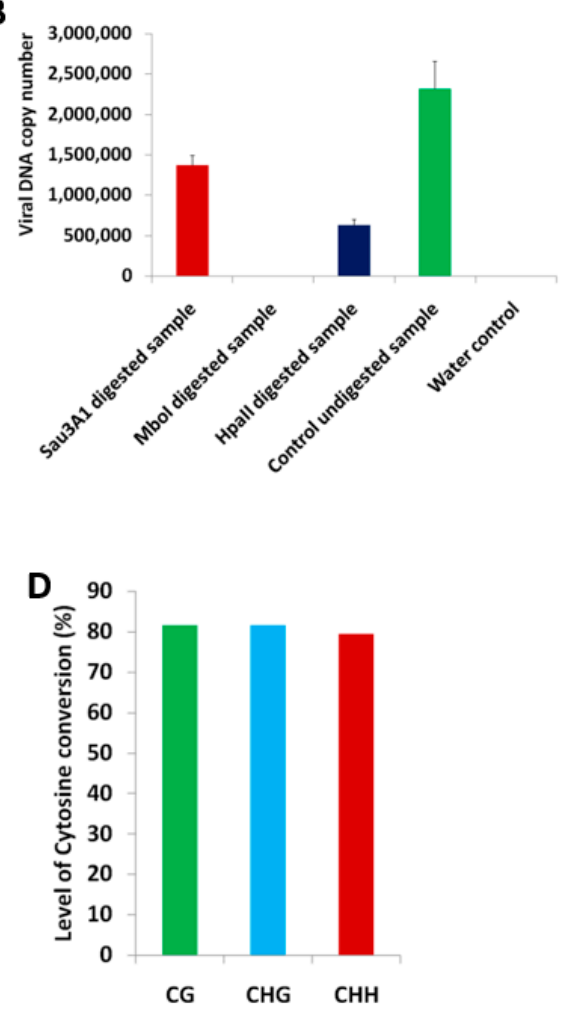

Figure 2. Quantitative PCR analysis of Methylation-sensitive enzyme-restricted products of BYVMV viral DNA from APTR along with $\beta$ PTR-infiltrated N. benthamiana, with BYVMV specific primer (A) and $\beta$ satellite specific primer (B). Level of cytosine conversion in Control DNA A sample (C) and Control DNA $\beta$ sample (D), where different methylation bases are plotted against the level of cytosine conversion. 
Table 1. List of primers used in the present study. The nucleotide substitutions are shown in bold face and underlined.

\begin{tabular}{|c|c|c|c|c|}
\hline S. No & Primers & Sequences & Target DNA \& Nucleotide Coordinate & Details of Experimental Use \\
\hline 1 & BYVMV DNA A IR Forward & $5^{\prime}$ GTTGACTATTTTTGAGACCCGATT 3' & BYVMV DNA (1-24) & Chop-PCR \\
\hline 2 & BYVMV DNA A IR Reverse & 5' GGATCCCACATTTTTTGAATTG 3' & BYVMV DNA A (285-264) & Chop-PCR \\
\hline 3 & BglII BYVMV AV2 Forward & $5^{\prime}$ AGATCTATGTGGGATCCACTATTAAACG $3^{\prime}$ & BYVMV DNA A (119-131) & Chop-PCR \\
\hline 4 & HindIII BYVMV AV2 Reverse & $5^{\prime}$ AAGCTTTCACATCCССТTGGAACATCC $3^{\prime}$ & BYVMV DNA A (485-465) & Chop-PCR \\
\hline 5 & HindIII BYVMV C2 Forward & $5^{\prime}$ AAGCTTATGCAGCATTCGTCTTTC $3^{\prime}$ & BYVMV DNA A (1584-1601) & Chop-PCR \\
\hline 6 & BglII BYVMV C2 Reverse & $5^{\prime}$ AGATCTTTAGAGATATTTGAGGAC $3^{\prime}$ & BYVMV DNA A (1170-1190) & Chop-PCR \\
\hline 7 & BamHI BYVMV AC4 Forward & $5^{\prime}$ GGATCCTTATCTTTAAGAACTCTAAGAGC $3^{\prime}$ & BYVMV DNA A (2130-2154) & Chop-PCR \\
\hline 8 & HindIII BYVMV AC4 Reverse & 5' AGCTTATGAAAATGGGGAACCTCATCTTCACG 3' & BYVMV DNA A (2438-2412) & Chop-PCR \\
\hline 9 & BglII BYVMV $\beta C 1$ Forward & $5^{\prime}$ AGATCTAATTATTATCTTATTATCAATAGTAC $3^{\prime}$ & BYVMV DNA $\beta(180-207)$ & Chop-PCR \\
\hline 10 & HindIII BYVMV $\beta C 1$ Reverse & $5^{\prime}$ AAGCTTATGAAAATATCTATACATTTCATC $3^{\prime}$ & BYVMV DNA $\beta(602-578)$ & Chop-PCR \\
\hline 11 & $\beta C 1$ Promoter Forward & 5' ATAATGTGTGGATGAAATTTATAGA $3^{\prime}$ & BYVMV DNA $\beta$ 603-627 & Chop-PCR \\
\hline 12 & $\beta C 1$ Promoter Reverse & 5' CTCATTTACCTATCGGTGTCTG 3' & BYVMV DNA $\beta$ 1080-1059 & Chop-PCR \\
\hline 13 & BYVMV V2 RT Forward & 5' GCAACTTTTGTCGCAGGATT $3^{\prime}$ & BYVMV DNA A (194-213) & Quantitative PCR \\
\hline 14 & BYVMV V2 RT Reverse & $5^{\prime}$ ATAGGCCTGTTTGTCCATGC $3^{\prime}$ & BYVMV DNA A (406-425) & Quantitative PCR \\
\hline 15 & BYVMV $\beta$ RT Forward & $5^{\prime}$ CGCGCGGTAAATGGTAAATA $3^{\prime}$ & BYVMV DNA $\beta(1017-1036)$ & Quantitative PCR \\
\hline 16 & BYVMV $\beta$ RT Reverse & $5^{\prime}$ CTACGACGCGCGATATAACT $3^{\prime}$ & BYVMV DNA $\beta$ (1158-1177) & Quantitative PCR \\
\hline 17 & C4 stop 1 Forward & 5' АTT TTCCTTCGAACTGGATTAGCACGTGAAGATGAGGTT 3' & BYVMV DNA A (2386-2426) & Site-specific mutagenesis \\
\hline 18 & C4 stop 1 Reverse & 5' AACCTCATCTTCACGTGCTAAATCCAGTTCGAAGGAAAAT 3' & BYVMV DNA A (2387-2426) & Site-specific mutagenesis \\
\hline 19 & C2 stop 1 Forward & 5' CCGAGTACAACGGTTGGGTTAGAAAGACGAATGCTGCAT 3' & BYVMV DNA A $1563-1600$ & Site-specific mutagenesis \\
\hline 20 & C2 stop 1 Reverse & 5' ATGCAGCATTCGTCTTTCT䇂ACCCAACCGTTGTACTCGG 3' & BYVMV DNA A 1600-1563 & Site-specific mutagenesis \\
\hline 21 & C2 stop 2 Forward & 5'CGCTTCCTTGTGTTGAACTT̄AGATTGGTACCCGAGTACA 3' & BYVMV DNA A 1533-1571 & Site-specific mutagenesis \\
\hline 22 & C2 stop 2 Reverse & $5^{\prime}$ TGTACTCGGGTACCAATCTAĀGTTCAACACAAGGAAGCG 3' & BYVMV DNA A 1571-1533 & Site-specific mutagenesis \\
\hline
\end{tabular}


High depth analysis on the control plasmid revealed a bisulfite conversion rate of $80-82 \%$ at $2 \mu \mathrm{g}$ (Figure 2D) and of 53-55\% at $4 \mu \mathrm{g}$ of the template DNA (Figure 2C). The 53-82\% bisulfite conversion may be due to different concentration and size of the plasmid which led us to keep $2 \mu \mathrm{g}$ viral DNA as a constant for the bisulfite treatment, anticipating $99 \%$ conversion owing to less size of the BYVMV $(2.7 \mathrm{~kb})$ and $\beta$ satellite $(1.3 \mathrm{~kb})$ than the control plasmids (pBlue DNA A 5.7 and pBlue $\beta 4.3 \mathrm{~kb}$ ). The viral DNA was isolated from the APTR- and $\beta$ PTR-infiltrated N. benthamiana plant at 21 dpi. Two micrograms of viral DNA was subjected to bisulfite treatment and converted to concatemers by RCA (rolling circle amplification) for NGS. The NGS data was analysed with COV (Coverage distribution of methylation sites) and MET (Methylation profiling) modules of MethGo. The percentage of methylation sites covered in the target DNA sequence is a critical factor for evaluating the quality of the sequencing data. Methylation sites with high coverage should provide accurate methylation status. The COV module of Methgo extracts the coverage value for each cytosine from the post-alignment data and subsequently produces a reverse cumulative plot for methylation sites in CG, CHG and CHH context where $\mathrm{H}$ refers to A, C or T [28] (Figure 3A). The coverage map generated by the COV module had showed about $95 \%$ coverage of the cytosine methylation sites on the BYVMV viral genome with the $10 \times$ depth assuring the sequencing quality and data consistency (Figure 3A,B). Data analysis by Methgo tool revealed roughly $14-18 \%$ (Figure 3C) methylation of CG, CHH and CHG sites. This was considered as base level methylation when APTR along with $\beta$ PTR were infiltrated.

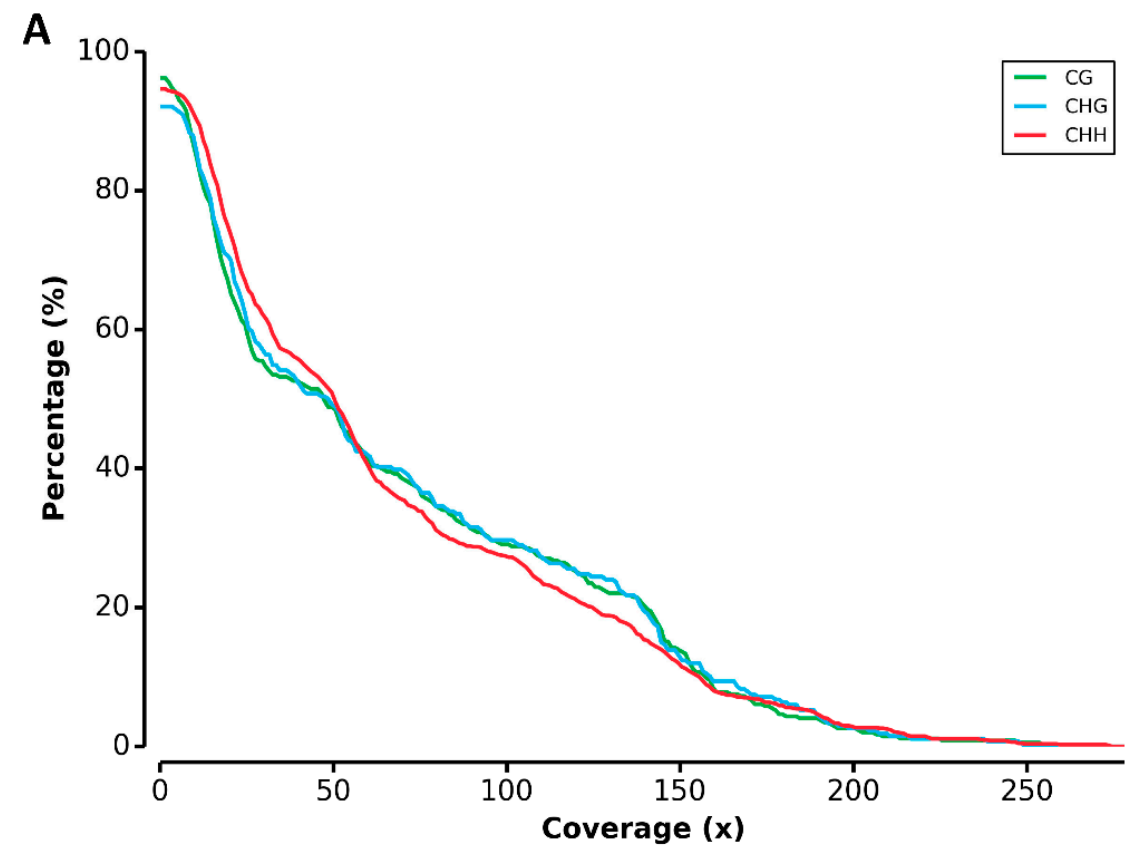

B

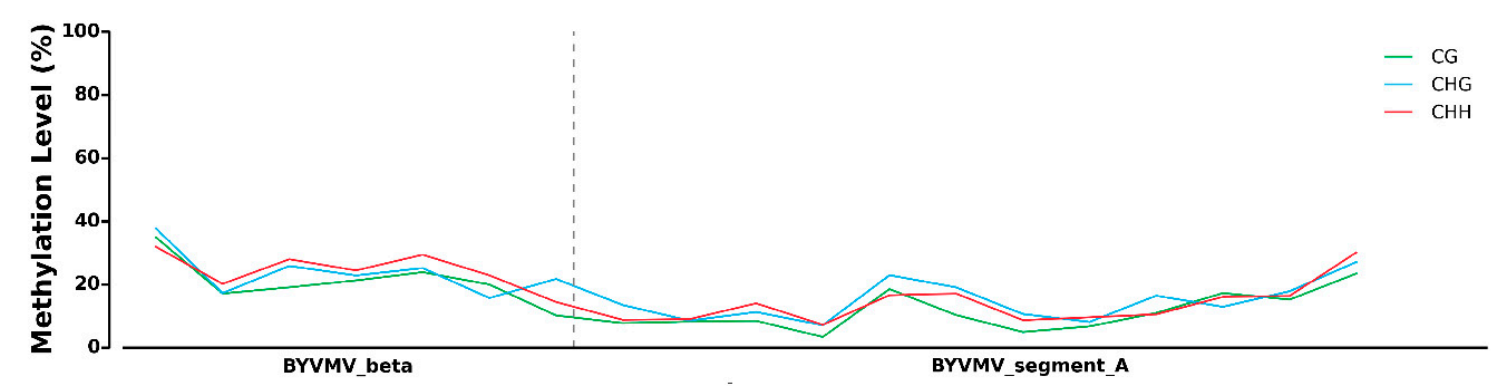

Figure 3. Cont. 


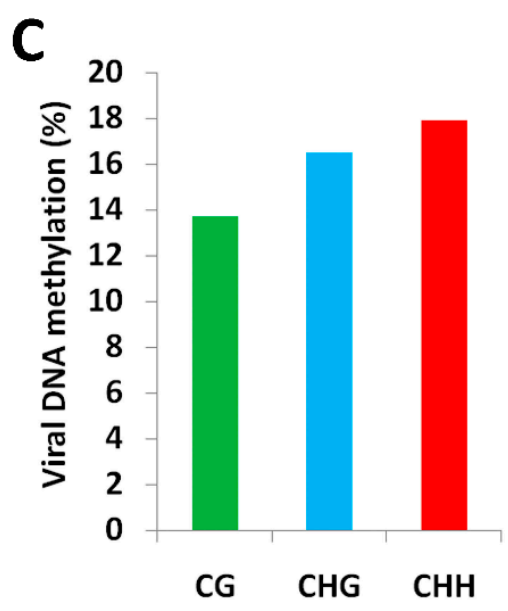

Figure 3. MethGo analysis of Bisulfite NGS Data for APTR and $\beta$ PTR co-infiltrated plant samples: Coverage of methylation sites is a criterion for assessing the quality and reliability of methylation data. The COV module of MethGo software extracts the coverage for each cytosine from BS-Seeker alignment file and generates a reverse cumulative plot for methylation sites in $\mathrm{CG}, \mathrm{CHG}$ and $\mathrm{CHH}$ context (where $\mathrm{H}$ refers to A, C or T). (A) Coverage map of 1 million Bisulfite NGS reads from APTR + $\beta$ PTR co-infiltrated plant sample. $y$-axis represents the percentage of methylation sites covered in the BYVMV genome. $x$-axis represents the depth of coverage $(x)$. (B) The genome-wide methylation map of BYVMV showing the level of methylation at different regions of BYVMV and $\beta$ satellite. (C) Global methylation pattern of BYVMV genome derived from 1 million reads and represented by plotting different methylation bases against percentage methylation.

\subsection{BYVMV Gene(s) Involved in Methylation Suppression}

Based on the chop-PCR, qPCR and high depth analysis of bisulfite sequencing data, we assured that BYVMV genes or $\beta C 1$ would have interfered with the DNA methylation. In order to identify whether BYVMV gene(s) were involved in TGS suppression, APTR alone infiltrated N. benthamiana plants were taken for further studies. The virus accumulation was confirmed by qPCR followed by Southern hybridization (Figure 4A,B). Chop-PCR was performed with various primers after digesting the viral DNA with MSREs and a significant reduction in amplification was found with at least one among the enzymes used when compared to the undigested one (Supplementary Figure S2). Chop-PCR analysis of $1.1 \mathrm{~kb}$ BYVMV genomic region which intervening between C4, V2 ORFs including IR, shows the complete absence of amplification in MSREs digested viral DNA samples. Interestingly, viral DNA copies determination by qPCR with MSREs digested viral DNA also demonstrates a more than $50 \%$ reduction in amplification, assuming that BYVMV genes should be involving in DNA methylation suppression (Figure 4C). In order to study the methylation pattern in an accurate manner, viral DNA isolated from APTR alone infiltrated $N$. benthamiana plants was subjected to bisulfite conversion and RCA. The concatamers were processed for Illumina sequencing as mentioned in the previous section.

The data that were analysed with one million reads by the MethGo software, which revealed approximately $4-5 \%$ methylation on a full-length BYVMV genome from the $N$. benthamiana plants, infiltrated with APTR alone (Figure 4D). Thus, we had confirmed the minimum level of DNA methylation in BYVMV. The coverage map generated by the COV module showed about $98 \%$ coverage of the cytosine methylation sites (Figure 5). Chop-PCR and high depth analysis of bisulfite reads inferred that BYVMV gene(s) were involved in the suppression of DNA methylation in $\beta C 1$. 

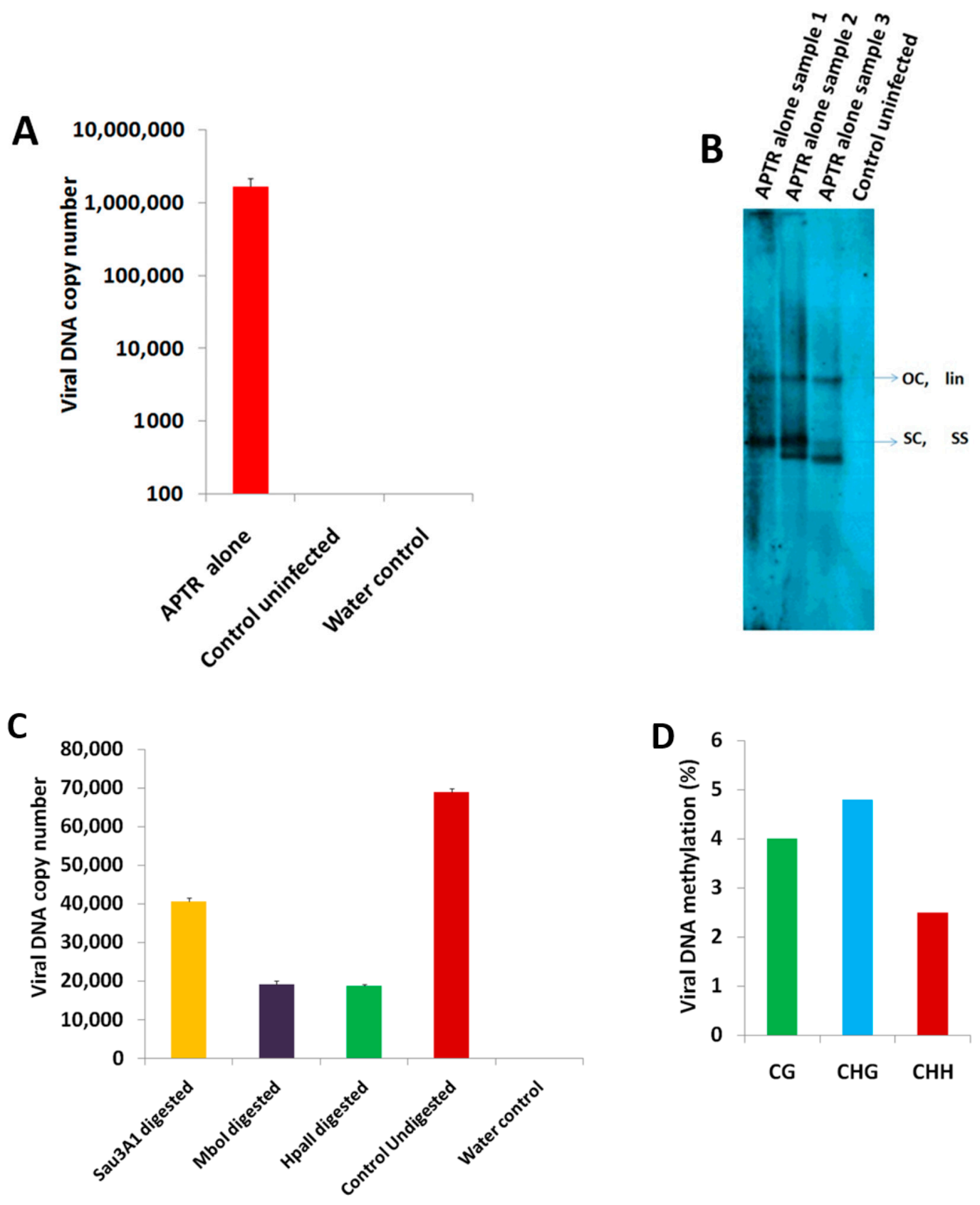

Figure 4. Confirmation of BYVMV DNA A accumulation in N. benthamiana plants. (A) qPCR of DNA derived from agroinfiltrated N. benthamiana with BYVMV-specific primers. (B) Southern confirmation of BYVMV in agroinfiltrated plants using DNA A probe. (C) Quantitative PCR of methylation-sensitive enzyme restricted products of viral DNA. (D) Global methylation pattern of BYVMV genome derived from 1 million reads and represented by plotting different methylation bases against percentage of methylation. 
A

B
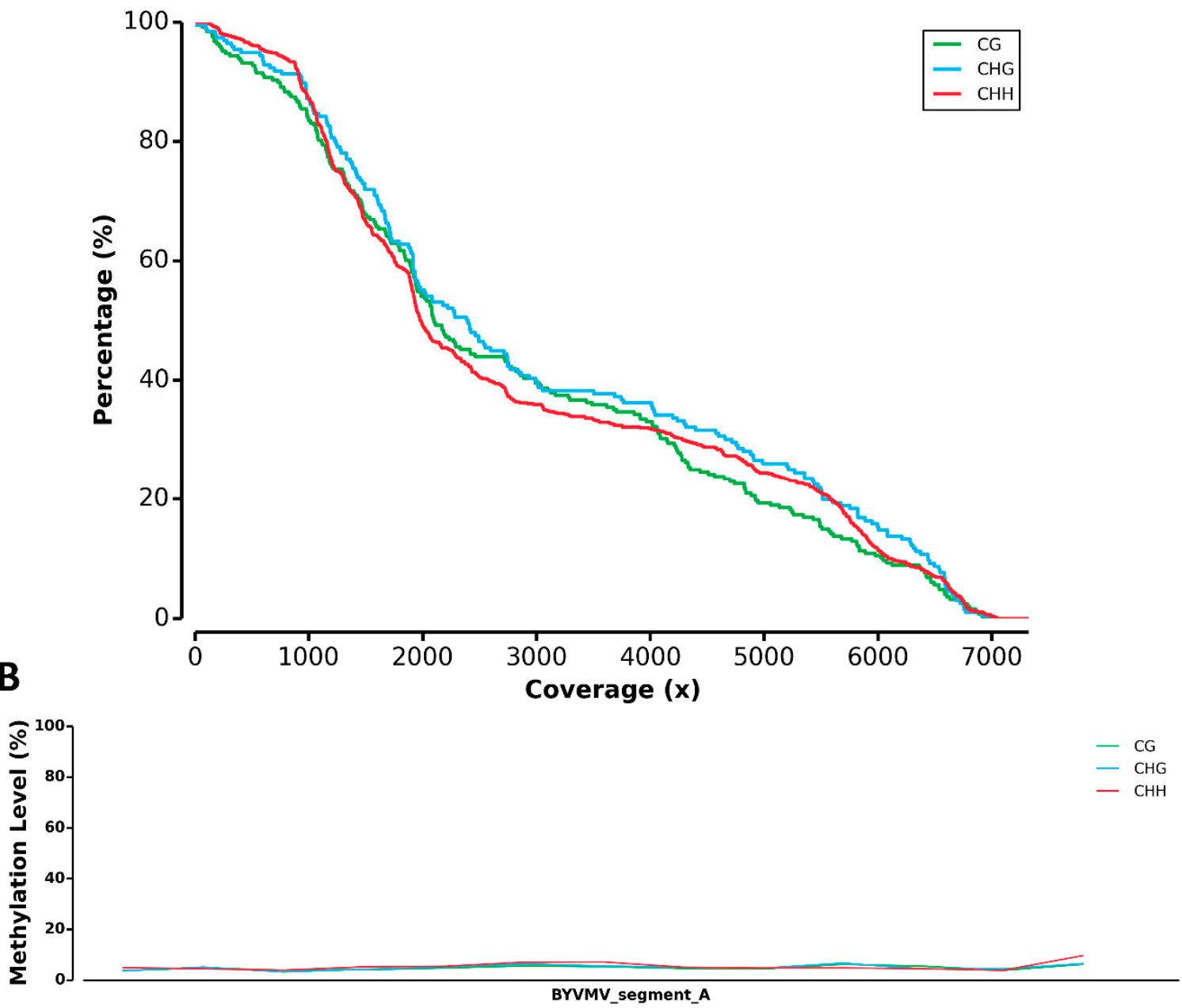

Figure 5. MethGo analysis of Bisulfite NGS Data for APTR alone infiltrated plant samples: (A) Coverage map of 1 million Bisulfite NGS reads. $y$-axis represents the percentage of methylation sites covered in the BYVMV. $x$-axis represents the depth of coverage $(x)$ which indicates high quality and reliability of the outcome. (B) The genome-wide methylation map of BYVMV showing the level of methylation at different regions of BYVMV.

\subsection{BYVMV C4 and C2 Hinders Transcriptional Gene Silencing}

Analyses of the results of chop-PCR and bisulfite NGS showed that BYVMV genes act as suppressors of TGS. These genes are C2 and C4 of BYVMV, since they are known to exert various degree of PTGS interference activity. Therefore, in the present study, initially, C4was chosen for further exploration, since C4 is a proven suppressor of gene silencing (TGS and PTGS) and symptom determinant $[22,29,30]$. To analyse BYVMV C4's role in TGS suppression, a mutant APTR (C4MAPTR) was produced by introducing a stop codon at the N-terminal region of $\mathrm{C} 4 \mathrm{ORF}$ using mutagenic primers (Table 1, Primers 17 and 18) without disrupting the overlapping C1 ORF. This produces a premature truncated 10 amino acid sequence of $C 4$. N. benthamiana plants, co-infiltrated with APTR and $\beta P T R$, showed leaf curling at $21 \mathrm{dpi}$ while APTR alone infiltrated plants producing mild symptoms (Figure 6A and Table 2). As expected, C4MAPTR (PTR construct of C4 mutant 'A' DNA) alone inoculated $N$. benthamiana plants remained asymptomatic (Figure 6A and Table 2). It was surprising that all $N$. benthamiana plants infiltrated with C4MAPTR along with $\beta$ PTR, were asymptomatic even at 40 dpi (Figure 6A). 
A

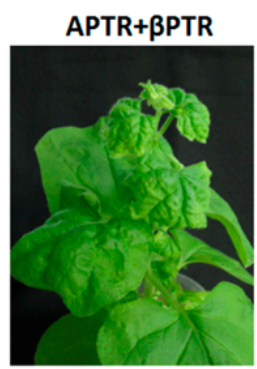

C4MAPTR alone

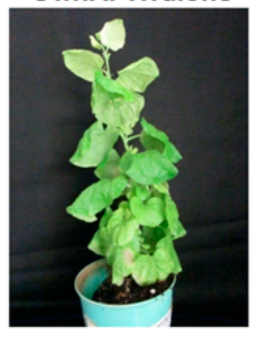

APTR alone

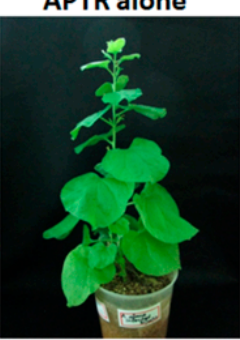

C4MAPTR + $\beta P T R$

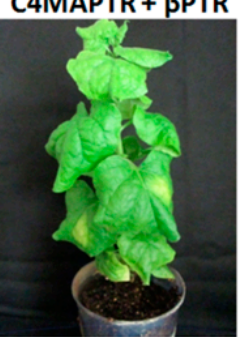

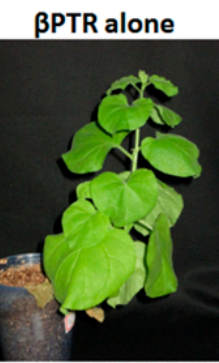

Wild $N$. benthamiana

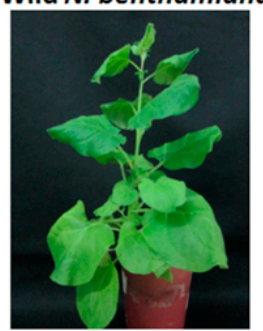

B ${ }_{100,000,000}$

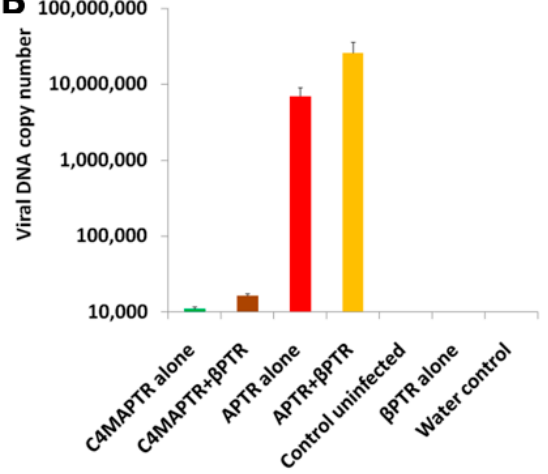

C ${ }_{100,000,000}$

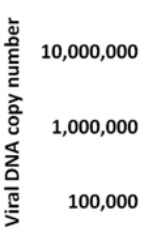

10,000
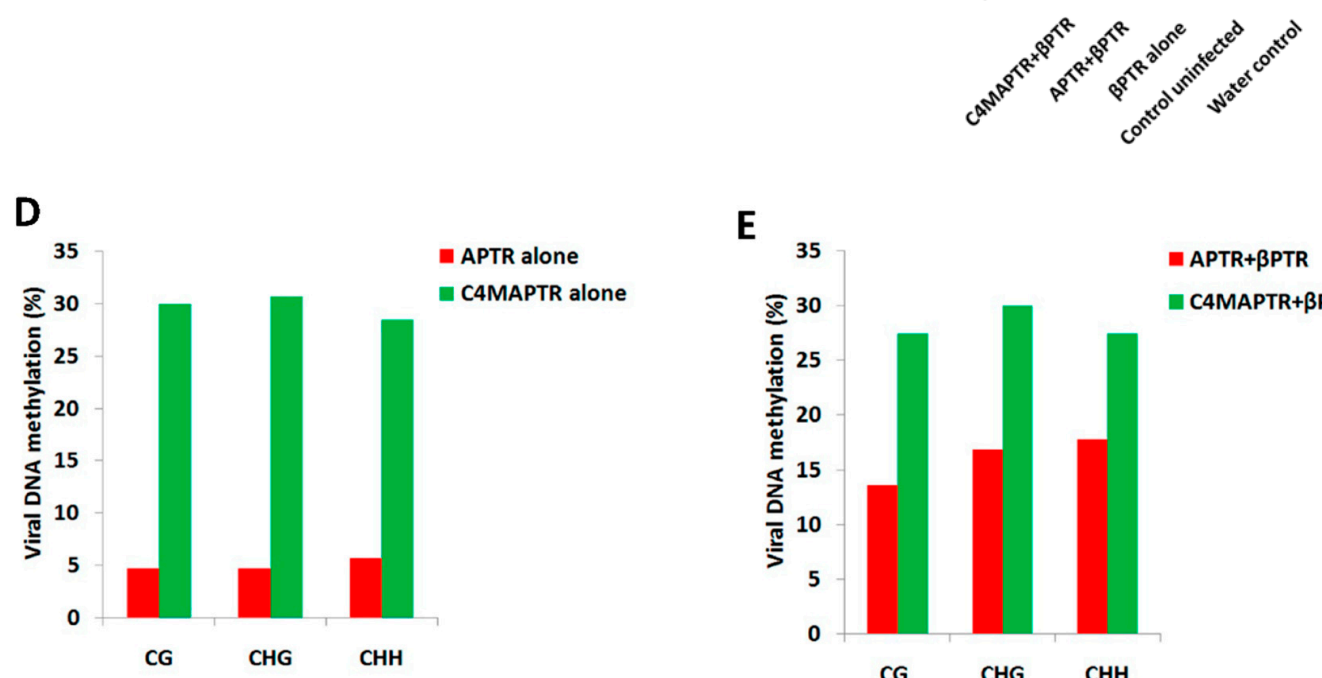

E

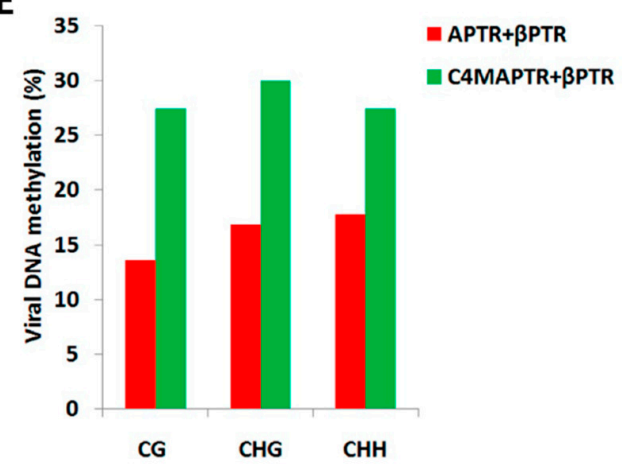

Figure 6. (A) Symptomatology of N. benthamiana plants infiltrated with various PTR constructs. Viral DNA isolated from plants of various PTR infiltrations, represented in Figure 6A, subjected to qPCR with BYVMV-specific primers (B) and $\beta$ satellite-specific primers (C) showing viral DNA accumulation. Comparison of the global percentage of methylation among different methylation base contexts between viral DNA derived from APTR alone (D) infiltrated plants and C4MAPTR alone infiltrated plants, APTR + $\beta$ PTR co-infiltrated plants and C4MAPTR + $\beta$ PTR co-infiltrated plants (E).

Table 2. Agroinfiltration of N.benthamiana plants.

\begin{tabular}{|c|c|c|c|c|c|}
\hline S.No & Type of Infiltration & $\begin{array}{c}\text { Total No. of } \\
\text { Plants Infiltrated }\end{array}$ & $\begin{array}{c}\text { Severe } \\
\text { Symptomatic Plants }\end{array}$ & $\begin{array}{c}\text { Mild } \\
\text { Symptomatic Plants }\end{array}$ & Asymptomatic \\
\hline 1 & APTR alone & 22 & 0 & 13 & 9 \\
\hline 2 & $\mathrm{APTR}+\beta \mathrm{PTR}$ & 27 & 13 & 4 & 10 \\
\hline 3 & C4MAPTR alone & 10 & 0 & 0 & 10 \\
\hline 4 & C4MAPTR + $\beta$ PTR & 10 & 0 & 0 & 10 \\
\hline 5 & C2MAPTR alone & 10 & 0 & 0 & 10 \\
\hline 6 & $\mathrm{C} 2 \mathrm{MAPTR}+\beta \mathrm{PTR}$ & 10 & 0 & 0 & 10 \\
\hline 7 & $\beta$ PTR alone & 14 & 0 & 0 & 14 \\
\hline
\end{tabular}


Viral DNA quantification by qPCR was done to explore the symptomatology of N. benthamiana plants infiltrated with C4MAPTR alone or C4MAPTR along with $\beta$ PTR or $\beta$ PTR alone. For all the infiltrated plants, DNA was extracted from all the leaves including the infiltrated leaves. As anticipated, APTR $+\beta$ PTR inoculated plants showed higher viral DNA titre $\left(2.5 \times 10^{7}\right.$ copies $)$ than APTR alone $\left(6.9 \times 10^{6}\right.$ copies) (Figure $\left.6 \mathrm{~B}, \mathrm{C}\right)$. However, C4MAPTR alone $\left(1.1 \times 10^{4}\right.$ copies $)$ or C4MAPTR along with $\beta$ PTR-infiltrated plants $\left(1.6 \times 10^{4}\right.$ copies) showed fewer copies of viral DNA (Figure $6 \mathrm{~B}, \mathrm{C}$ ). This suggests $\mathrm{C} 4$ is having additional function(s) for the virus survival by being involved in replication or cell to cell movement or TGS suppression. The viral DNA was extracted from C4MAPTR-infiltrated $N$. benthamiana plant leaves at $21 \mathrm{dpi}$. Bisulfite conversion and RCA were performed with this DNA. To know the methylation pattern, viral DNA from plant leaves infiltrated with APTR alone or APTR along with $\beta$ PTR or C4MAPTR alone or C4MAPTR along with $\beta$ PTR, were used for bisulfite NGS. Exploring the coverage map of APTR alone and APTR along with $\beta$ PTR revealed $98 \%$ and $80 \%$ coverage of methylation sites with a depth of $100 \times$ and $10 \times$, respectively. This was similar to C4MAPTR inoculated N. benthamiana samples except for coverage depth (Supplementary Figures S3 and S4). The bisulfite data analysis of the viral genome derived from $N$. benthamiana plants infiltrated with APTR alone ( $\sim 0.6$ million reads) or APTR along with $\beta$ PTR ( $\sim 0.7$ million reads) showed consistent results that were observed in the previous data of wild type DNA infiltration (Figure 6D,E).

Intriguingly, the viral genome from plants infiltrated with C4MAPTR alone ( $\sim 2.6$ million reads) showed $28-30 \%$ methylation compared to $4-5 \%$ methylation of the viral genome from plants infiltrated with APTR alone (Figure 6D). The viral genome from the $N$. benthamiana plants infiltrated with C4MAPTR along with $\beta$ PTR ( $\sim 2$ million reads) revealed $\sim 27-30 \%$ methylation compared to $\sim 14-18 \%$ of APTR and $\beta$ PTR together (Figure $6 \mathrm{E}$ ). When C4MAPTR alone or C4MAPTR along with $\beta$ PTR were infiltrated, the viral genome from the plants showed an altered level of methylation $(\sim 27-30 \%)$ compared to the infiltration of wild type constructs $(\sim 5-18 \%)$. These results imply that the genome of BYVMV becomes susceptible to methylation in the absence of $C 4$, since $C 4$ mutation renders inefficient suppression of DNA methylation (Figure 6D,E).

Previous reports confirmed BYVMV C2 as a strong transactivator and weak suppressor of PTGS [22]. It was also demonstrated that $\mathrm{AC} 2 / \mathrm{C} 2$ effectively interfered with the DNA methylation by interacting with the methylation cycle proteins [15-18]. To evaluate the role of C2 on TGS impairment, the C2-deficient infectious construct (C2MAPTR) was infiltrated into $N$. benthamiana plants either as C2MAPTR alone or along with the $\beta$ satellite ( $\beta$ PTR). All the C2 mutant construct- infiltrated plants were asymptomatic whereas the constructs of wild type BYVMV alone or BYVMV along with $\beta$ satellite-infiltrated plants showed symptoms at $21 \mathrm{dpi}$ [23] (Table 2). The qPCR analysis showed high accumulation of viral DNA in the plants infiltrated with APTR alone $\left(7 \times 10^{6}\right.$ copies $)$ and APTR along with $\beta$ PTR $\left(1.3 \times 10^{7}\right.$ copies $)$ and less viral DNA accumulation in the plants infiltrated with C2MAPTR alone $\left(5 \times 10^{3}\right.$ copies) or C2MAPTR along with $\beta$ PTR $\left(9.1 \times 10^{5}\right.$ copies $)$ (Figure 7A,B).

In order to reveal the methylation profiles of the viral DNA from plants infiltrated with C2MAPTR alone or C2MAPTR along with $\beta$ PTR, bisulfite NGS was performed. Coverage analysis of APTR alone or along with $\beta$ PTR showed $~ 90 \%$ and $85 \%$ coverage of methylation sites with a depth of $200 \times$ and $10 \times$, respectively. Similarly, we found $98 \%$ and $80 \%$ coverage of methylation sites for C2MAPTR alone or along with $\beta$ PTR samples with a depth of $10 \times$ and $100 \times$, respectively (Supplementary Figures S5 and S6). The analyses of the viral genome were done on $\sim 0.6$ million reads from plants infiltrated with APTR alone, $\sim 0.7$ million reads from plants infiltrated with APTR along with $\beta$ PTR, $\sim 2.8$ million reads from plants infiltrated with C2MAPTR alone and $\sim 3.2$ million reads from plants infiltrated with C2MAPTR along with $\beta$ PTR. The analyses showed $4-6 \%$ methylation of viral DNA in APTR alone infiltrated plants, $13-18 \%$ methylation of viral DNA in APTR along with $\beta$ PTR infiltrated plants, 14-18\% methylation of viral DNA in C2MAPTR alone infiltrated plants and 55-60\% methylation of viral DNA in C2MAPTR along with $\beta$ PTR infiltrated plants (Figure 7C,D). The MET module analyses of methylation pattern by MethGo showed an increased methylation of the viral genome when plants were infiltrated with C2MAPTR alone or C2MAPTR along with $\beta$ PTR. This value is significant when 
compared to the methylation values of the viral genome from plants infiltrated with APTR along with $\beta P T R$ (Figure 7C,D). In conclusion, the viral genome methylation of plants infiltrated with C2MAPTR showed a higher value in the presence of $\beta$ satellite, which signifies the higher level of $C 2$ involvement in TGS suppression.

A

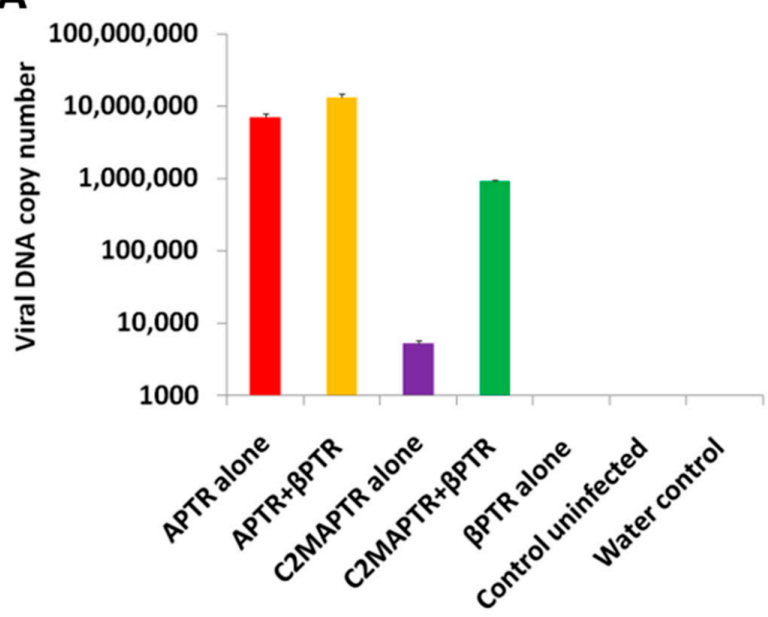

B

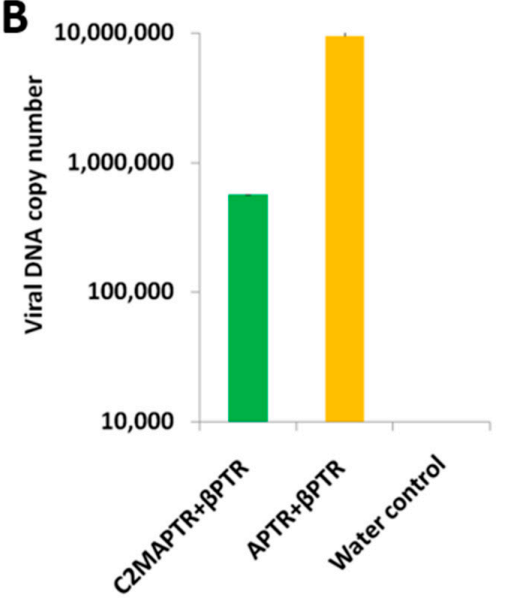

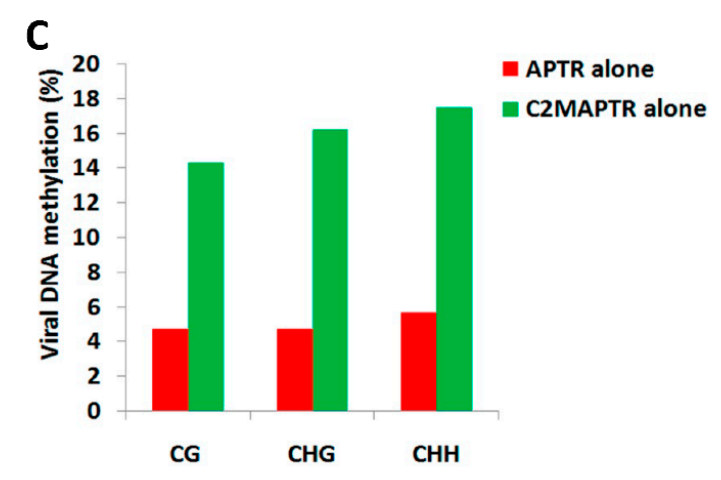

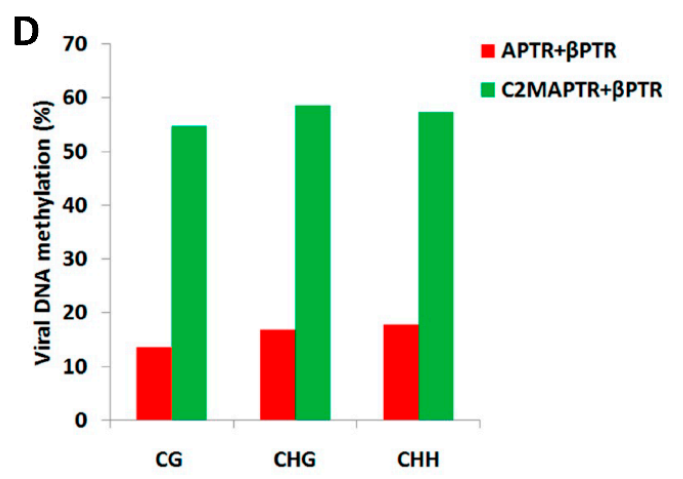

Figure 7. Copy number detection by qPCR. Viral DNA was isolated from the N. benthamiana plants infiltrated with various PTR constructs and copy number were determined using BYVMV-specific (A) and $\beta$ satelite-specific primers (B). Comparison of global percentage of methylation among different methylation base contexts between viral DNA derived from APTR alone infiltrated plants and C2MAPTR alone infiltrated plants $(C)$, APTR + $\beta$ PTR co-infiltrated plants and C2MAPTR $+\beta P T R$ co-infiltrated plants (D).

\subsection{C4 Mutation Impairs Viral Movement}

Plants were infiltrated with APTR alone or APTR along with $\beta$ PTR or C4MAPTR alone or C4MAPTR along with $\beta P T R$, to find out the influence of $C 4$ on replication and movement. qPCR was performed on leaves harvested from the inoculated $N$. benthamiana and newly emerged leaves to determine the BYVMV viral DNA accumulation. In order to avoid the initial template of viral DNA raised from the agroiniltration, the enriched viral DNA was subjected to $D p n$ I digestion. Viral DNA quantification on inoculated leaves of $N$. benthamiana at 2 dpi showed prominent viral DNA accumulation in C4MAPTR-infiltrated leaves which was similar to APTR alone or along with $\beta$ PTR (Figure $8 \mathrm{~A}, \mathrm{C}$ ). On the other hand, qPCR results of the emerging leaves from the plants infiltrated either with C4MAPTR alone (32 copies) or C4MAPTR along with BPTR (54 copies) at 21 dpi showed less copies of viral DNA. (Figure 8B,D). These plants were asymptomatic too. However, when APTR alone or APTR along with $\beta$ PTR was infiltrated into $N$. benthamiana plants, they showed a high level of viral accumulations in emerging leaves with mild or severe symptoms respectively at 21 dpi (Figure 8B,D). 
A
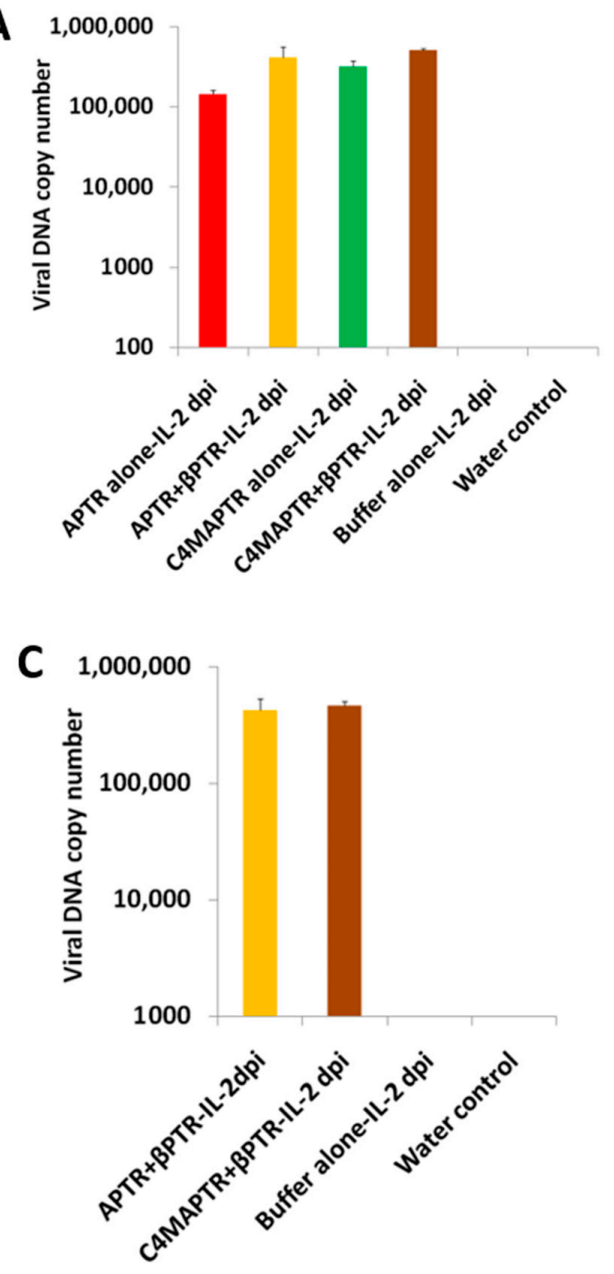

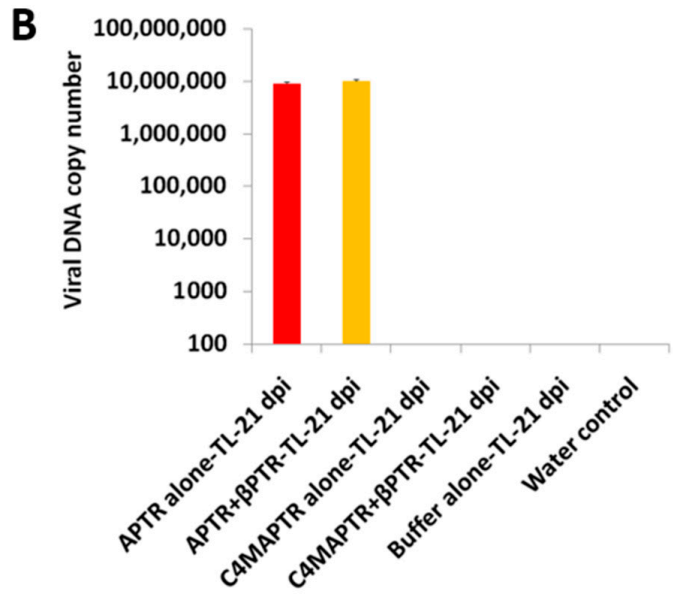

D

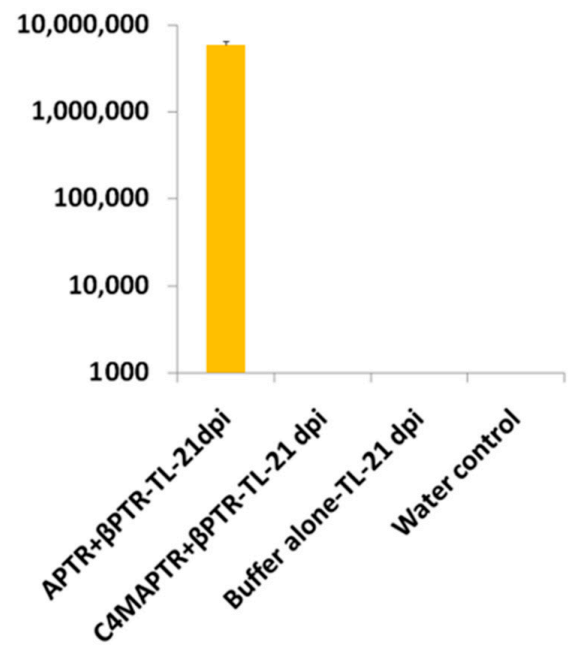

Figure 8. Copy number determination at different dpi. (A) BYVMV-specific primer mediated qPCR, showing the copy number of DNA A derived from $N$. benthamiana infiltrated with various PTR constructs of BYVMV at 2 dpi. (B) BYVMV-specific primer mediated qPCR, showing the copy number of viral DNA derived from $N$. benthamiana infiltrated with various PTR constructs of BYVMV at 21 dpi. (C) $\beta$ satellite-specific primer mediated qPCR, showing the copy number of $\beta$ satelite derived from $N$. benthamiana infiltrated with various PTR constructs of BYVMV at 2 dpi. (D) $\beta$ satellite-specific primer mediated qPCR, showing the copy number of $\beta$ satellite derived from $N$. benthamiana infiltrated with various PTR constructs of BYVMV at $21 \mathrm{dpi}$ (IL-Infiltrated Leaf, TL-Top leaf, dpi-days of post infiltration).

The less viral DNA accumulation in emerging leaves of $N$. benthamiana must be due to the limited spread of virus movement. All these results confirmed the involvement of $\mathrm{C} 4$ in the movement of the virus in replication. Since it is established that C4 is involved in viral movement, its role in replication could be confirmed with a protoplast assay. Viral DNA accumulation in the protoplast was assessed with a standardised transfection protocol and viral DNA was extracted after 3 days of transfection followed by $D p n \mathrm{I}$ digestion to remove the initial template caused by the transfection. The assessment of viral DNA quantity in protoplasts transfected with APTR alone or C4MAPTR alone or APTR/C4MAPTR along with $\beta$ PTR, showed an increased value (Figure 9A,B). The increased quantity of viral DNA accumulation upon protoplast transfection with C4MAPTR alone or along with $\beta$ PTR, suggests that $C 4$ is not an impediment for viral replication. The assay with the emerging leaves and protoplasts confirms the involvement of C4 in viral DNA movement. 


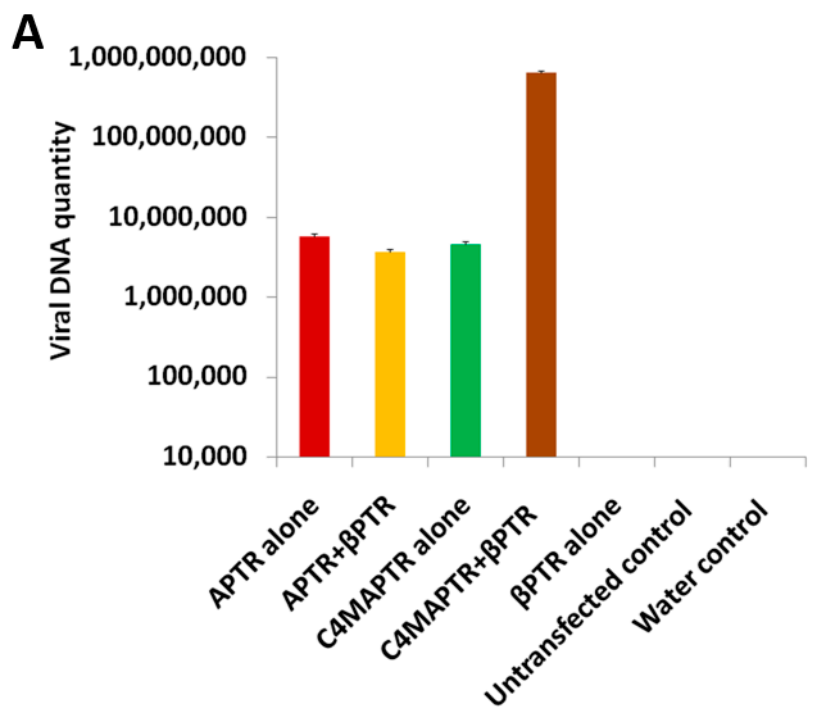

B

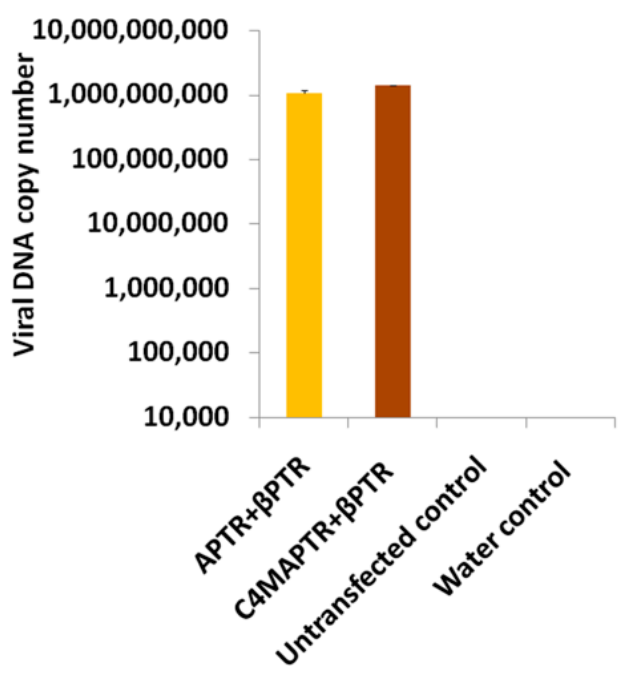

Figure 9. Evaluation of viral DNA accumulation in Protoplasts. Quantitative PCR using BYVMV-specific primer (A) and using $\beta$ satelite-specific primer (B) showing the copy number of viral DNA from the mesophyll protoplasts of $N$. benthamiana when transfected with various PTR constructs of BYVMV.

\section{Discussion}

Small RNAs (sRNAs) produced by the plants are specific in targeting the RNA of the invading viruses as an endeavour of PTGS [31-33]. As a counter activity, geminiviruses encode an array of proteins (i.e., C2, C4, V2, C5 and $\beta C 1$ ) which have the property to impair PTGS. It has been already established that BYVMV has three suppressors that are involved in PTGS hindrance. Further geminiviral double-stranded DNA intermediates are the potential target of RNA-mediated DNA methylation (RdDM) which is accomplished by short interfering RNAs (siRNAs). This in turn hinders geminiviral gene transcription and DNA replication at chromatin level. The notion that the repressive epigenetic mark of TGS established against geminiviral chromatin, comes from several lines of evidence which describe DNA methylation as an effective arm to hinder viral replication. However, the geminiviruses have a group of proteins-AC2/C2, V2, AC1 of begomoviruses and $\beta C 1$ of $\beta$ satellite $[16,34-37]$ to counteract the TGS mechanism. Based on these observations, it was speculated that BYVMV, a monopartite geminivirus, should encode TGS suppressors. To evaluate BYVMV interference with the DNA methylation, the accumulation of BYVMV was assessed by qPCR 
in the plants infiltrated with PTRs of BYVMV alone or along with $\beta$ satellite and the $C 2$ and $C 4$ mutated genome. Chop-PCR analyses demonstrated that BYVMV gene(s) were involved in the prevention of methylation (Supplementary Figure S2). To substantiate the results of chop-PCR, high depth bisulfite sequencing was done. This confirmed that the viral genomes from plants, infiltrated with either BYVMV APTR alone or along with $\beta$ PTR, were having less than $4-18 \%$ methylation. These data analyses clearly prove that BYVMV impaired the DNA methylation. Similar results were derived from Tomato golden mosaic virus (TGMV), Beet curly top virus (BCTV), Tomato yellow leaf curl China virus (TYLCCV) and Tomato yellow leaf curl Sardinia virus (TYLCSV) $[16,17,34,35]$. Almost in all cases, the conventional cloning method was used to predict the methylation level from 10-20 clones of viral DNA. In contrast, in the present study, we used NGS to generate a million reads to reveal the methylation status of the BYVMV genome, which providesa more consistent and accurate methylation level than traditional approaches.

The Previous studies with TYLCCV, East African cassava mosaic Cameron virus (EACMCV) and African cassava mosaic virus-Cameron (ACMV-CM) confirmed the role of $\mathrm{C} 4$ in symptom production and suppression of PTGS [27-29]. Hence, the C4 mutant BYVMV (C4MAPTR) was taken for initial studies. However, the C4MAPTR-infiltrated $N$. benthamiana plants remained asymptomatic even when it was infiltrated along with cognate $\beta$ satellite ( $\beta$ PTR), which is known for its symptom severity $[19,22]$. The qPCR of the viral genome derived from plants infiltrated with C4MAPTR alone $\left(1.1 \times 10^{4}\right.$ copies $)$ or C4MAPTR along with $\beta$ PTR $\left(1.6 \times 10^{4}\right.$ copies $)$, showed lower viral DNA accumulation than wild type PTR constructs (Figure 6B,C). The analysis of methylation profiles using MethGo showed 28-30\% methylation of the viral genome from plants infiltrated with C4MAPTR alone or C4MAPTR along with $\beta$ PTR (Figure $6 \mathrm{D}, \mathrm{E}$ ). This suggests that $\mathrm{C} 4$ is involved in the suppression of TGS. Earlier, it had been shown that the C4-deficient TYLCV-Sardinia and Tomato leaf curl virus (ToLCV-Australia) remained infectious with a significant difference in symptoms compared to the wild type virus [38]. Consequently, it has been shown that BCTV or ToLCV-Australia C4 produced virus-like symptoms when expressed in transgenic tobacco or tomato [39,40], representing C4 participation in symptom development. In the present work, BYVMV C4 was studied and demonstrated for its role in symptom determination, as observed in earlier studies. Further, its role in TGS suppression was also studied since the suppression of DNA methylation and the reversal of TGS by C4 was reported only with a natural recombinant begomovirus (Y194) infecting Malvastrum coromandelianum. The Y194 C4 is almost identical (84 out of 85 amino acids) to that of Pepper leaf curl china virus (PepYLCCNV) and the nucleotide sequence except the C4 gene has $\sim 97 \%$ identity with TYLCCNV [29]. The DNA methylation suppressor activity of C4 from Y194 virus has been elucidated by analysing the 25 bisulfite clones which represent the methylation status in the particular $366 \mathrm{nt}$ long viral DNA fragment. Whereas in the present study, the DNA methylation suppressor activity of BYVMV C4 has been proved by analysing $\sim 2.6$ million bisulfite reads from C4MAPTR alone and $\sim 2$ million reads from C4MAPTR along with $\beta P T R$ infiltrated samples. It is interesting to note that millions of BYVMV reads were mapped with all over its genome which in turn gave a highly accurate methylation status. When compared to $\sim 4-18 \%$ viral DNA methylation level of either APTR alone or APTR along with $\beta$ PTR samples, $\sim 28-30 \%$ of viral DNA methylation with either C4MAPTR alone or along with $\beta$ PTR confirms the role of BYVMV $C 4$ in viral DNA methylation suppression. When the $C 4$ mutant constructs infiltrated in N. benthamiana plants either alone or along with $\beta$ satellite, the emerging leaves were totally devoid of BYVMV accumulation. In addition, the protoplast assay with C4MAPTR showed the retention of replication potential like APTR. This confirmed that $\mathrm{C} 4$ was not an impediment for viral DNA replication but was involved in the viral movement. In monopartite begomoviruses, the V1 might have NSP activity as had been reported in Tomato leaf curl virus, Israel (TYLCV-Is). In TYLCV-Is the CP was localized in the nucleus which retained the import and export processes [41-43]. The CP of TYLCV-Is also displayed a high affinity toward ssDNA molecules with slight binding property with double-stranded DNA (dsDNA) [43]. It has both nuclear localization signal (NLS) and nuclear exporting (NES) signal which enable the nucleo-cytoplasmic transport of TYLCV DNA [41,43]. Similarly, the CP of BYVMV was also 
found to be localized in the nucleus since it has NLS and NES [44]. However, there is an ambiguity regarding the proteins involved in movement. The earlier reports had proposed that $\mathrm{V} 2$ or $\mathrm{C} 4 \mathrm{might}$ act as movement protein (MP) without concrete evidence [38,41,45,46]. Based on these results, we are proposing that BYVMV C4 should act as an MP. This has to be confirmed by performing DNA binding, cellular localization and protein-protein interaction studies with the $\mathrm{C} 4$ and $\mathrm{CP}$.

Previously, it had been shown that AC2/C2 of TGMV/BCTV could perturb TGS and drastically reduce the plant DNA methylation by inactivating Adenosine kinase (ADK) of the methyl cycle $[34,35,47]$. In yet another mechanism, it had been confirmed that C2 functioned as an impediment for the proteasome-mediated degradation of $S$-adenosyl-methionine decarboxylase 1 (SAMDC1) [35]. This led to acute disturbance in the balance between S-adenosine methionine (SAM) and decarboxylated S-adenosine methionine (dcSAM). Based on these observations of AC2/C2 role in TGS interference, BYVMV C2 was selected for further exploration, since it had already demonstrated to be a strong transactivator and a week suppressor of PTGS [22]. Indeed, the C2 mutation led to a drastic reduction in the viral DNA accumulation (Figure 7A). High depth bisulfite sequencing analysis demonstrated that C2 was a suppressor of TGS like the AC2/C2 of TGMV, BCTV and BSCTV $[35,48]$. However, C2MAPTR along with $\beta$ PTR-infiltrated N.benthamiana plant showed 55-60\% methylation, which is higher than C4MAPTR alone or along with $\beta$ PTR $(28-30 \%)$. The exact reason remains to be deciphered for the presence of hypermethylation on viral DNA upon C2MAPTR along with $\beta$ PTR infection. Probably itmay be due to viral DNA accumulation or other reasons. The BYVMV C2 mutation had reduced the viral DNA accumulation by producing hypermethylation on the BYVMV genome in CG, CHG and CHH context (Figure 7C,D). This suggested that $\mathrm{C} 2$ had influenced the common methylation cycle than a particular methyltransferase activity. It is interesting to note that $\beta C 1$ had been shown to impair the TGS by inhibiting the activity of S-adenosyl homocysteine hydrolase (SAHH) [18]. However, BYVMV $\beta C 1$ did not have any role on the TGS interference, since C4MAPTR or C2MAPTR inoculated along with $\beta$ PTR revealed hypermethylation. Though TGS suppressor activity was exhibited by $\mathrm{C} 2$ and $\mathrm{C} 4$, the symptom production and viral DNA accumulation was lesser when $N$. benthamiana plants were infiltrated with APTR alone than APTR along with $\beta$ PTR. This is because $\beta C 1$ is a multifunctional protein, known to play a stronger role in PTGS suppression and symptom determination than $\mathrm{C} 2$ and $\mathrm{C} 4$ [22]. Further it also interacts with many host proteins and enhances viral DNA accumulation and symptom production [25,49]. Hence, it is concluded that the effective infection in host plants is governed by a cumulative activity of $C 2, C 4$ and $\beta C 1$.

\section{Materials and Methods}

\subsection{Cloning}

pAPTR4 plasmid containing full-length DNA-A of BYVMV (2741 nt) (GenBank Accession No: AF241479.1) [19] was used for making a mutation in the $N$-terminal of C4 ORF. The entire C4 ORF lies within the C1 ORF under the complementary reading frame (Figure 1E). A stop codon was introduced in the N-terminal of C4 ORF at the 11th amino acid (UCA to UAA) by a single nucleotide change by using mutagenic primers (Table 1, Primers 17 and 18) without affecting the $C 1$ coding sequence. The PCR conditions and DpnI digestion were performed as per the manufacturer's instructions (Thermo Scientific, Waltham, MA, USA). The plasmid containing the specific mutation in the N-terminal of C4 ORF was selected and named as pKK1.The full-length BYVMV containing the mutated $\mathrm{C} 4$ sequence was released from $\mathrm{pKK} 1$ by EcoRV and SacI digestion and the resulting $2.7 \mathrm{~kb}$ BYVMV fragment was cloned in the same restriction sites of pAPTR5. Thus, 1.9 mer APTR plasmid was created and the plasmid was renamed as pKK2. A $600 \mathrm{bp}$ fragment containing the intergenic region (IR) and a part of $\mathrm{C} 1$ and V2 ORF was released from pOK12 [50] 0.2 mer A DNA plasmid [23] by $S a c I$ and EcoRV digestion. This 600 bp fragment was cloned in pKK2 on the same restriction sites and the resulting clone was named as pKK3 1.2 mer. This pKK3 clone contains PTR on both sides of the BYVMV. The entire 1.2 mer APTR was released from pKK3 by SalI and SacI digestion and the 
released fragment was cloned into pBIN PLUS vector at the corresponding sites. The resulting plasmid was renamed as pBIN-C4MAPTR, mobilized to Agrobacterium strain EHA 105 by triparental mating and then used for agroinfiltration experiments [51].

pCAMBIA C2MAPTR construct was created by Sam Aldrin [23]. Briefly, two stop codons were introduced in the N-terminal region of $\mathrm{C} 2$ by using mutagenic primers (Table 1, Primers 19-22). C2 mutations were introduced in the pAPTR4 plasmid which contained full length A DNA. In C2 ORF, the seventh serine residue and tenth lysine residue was converted into stop codons. pAPTR4 containing two $\mathrm{C} 2$ mutations was digested with EcoRV and SacI and cloned in pAPTR5 to produce pC2mut-APTR6, which contains a wild type copy of C2 ORF. In order to remove the wild type C2, a $600 \mathrm{bp}$ BYVMV fragment was released from pOK 0.2 mer by digestion with EcoRV and XhoI and cloned into pC2MAPTR6 at the site of EcoRV and SalI. This created pBKS 1.2 mer C2MAPTR. The pBKS 1.2 mer C2MAPTR was digested with SacI and XhoI and cloned into pCAMBIA 2301 at the site of SacI and SalI to produce pCAMBIA-C2MAPTR (C2MAPTR). All the clones were confirmed by restriction digestion.

\subsection{Agroinfiltration}

The PTR constructs of BYVMV was mobilized into Agrobacterium tumefaciens strain LBA 4404 or EHA 105 by triparental mating. Agroinfiltration was performed as reported previously [22,31]. Briefly, the transconjugants were grown in $50 \mathrm{~mL}$ of $\mathrm{AB}$ broth $(\mathrm{AB}$ media salts $+\mathrm{AB}$ media Buffer + Glucose $(0.5 \mathrm{~g} / 100 \mathrm{~mL})$ ) with the respective antibiotics (Rifampicin $-10 \mu \mathrm{g} / \mathrm{mL}$, Kanamycin $-50 \mu \mathrm{g} / \mathrm{mL}$ ) and $100 \mu \mathrm{M}$ Acetosyringone. The cells were pelleted by centrifugation at $6000 \mathrm{rpm}$ for $5 \mathrm{~min}$ at $0.5 \mathrm{OD}_{600}$. The pelletted culture was then resuspended in an infiltration medium $[10 \mathrm{mM} \mathrm{MgCl}, 10 \mathrm{mM}$ MES pH 5.5, Acetosyringone $(100 \mu \mathrm{M})]$. The wild type N. benthamiana plants were used for the infiltration studies. For co-infiltration, each Agrobacterium tumefaciens culture was grown up to $\mathrm{OD}_{600} 0.5$ and equal volume was mixed prior to infiltration.

\subsection{Viral DNA Isolation}

Viral DNA was extracted from the total leaves (both the infiltrated and non-filtrated leaves) or specifically infiltrated leaves of $N$. benthamiana by CTAB-alkaline lysis method [52]. $1 \mathrm{~g}$ of N. benthamiana leaf sample was ground with liquid $\mathrm{N} 2$ and thoroughly mixed with $10 \mathrm{~mL}$ of $2 \times \mathrm{CTAB}$. The ground homogenous mixer was transferred to $2 \mathrm{~mL}$ tubes and kept at $60{ }^{\circ} \mathrm{C}$ for $5-10 \mathrm{~min}$ to neutralize the degrading enzymes. The samples were brought to room temperature and the total DNA was isolated via conventional Chloroform: Isoamyl alcohol (24:1) wash and absolute alcohol precipitation method. The final aliquot was resuspended in $200 \mu \mathrm{L}$ of $0.1 \times$ Tris-EDTA (TE) buffer $\mathrm{pH} 8$. In the case of viral DNA isolated from infiltrated leaf, the samples were treated with a DpnI enzyme to remove the initial template coming from the bacteria. With this aliquot $400 \mu \mathrm{L}$ of freshly prepared $1 \%$ SDS and $0.2 \mathrm{M}$ $\mathrm{NaOH}$ solution was added. The contents were mixed thoroughly and kept on ice for $15 \mathrm{~min}$. With these contents $300 \mu \mathrm{L}$ of $3 \mathrm{M}$ sodium acetate ( $\mathrm{pH}$ 5.2) was added. The contents were mixed gently and kept on ice for $30 \mathrm{~min}$. The tubes were centrifuged at $10,000 \mathrm{rpm}$ for $10 \mathrm{~min}$ at $4{ }^{\circ} \mathrm{C}$ and the top supernatant was transferred to a new tube. Along with this content, an equal volume of absolute alcohol was added and mixed well. The solution was kept for precipitation at $-20{ }^{\circ} \mathrm{C}$ for $2 \mathrm{~h}$. The tubes were centrifuged at $12,000 \mathrm{rpm}$ for $10 \mathrm{~min}$ at $4{ }^{\circ} \mathrm{C}$. The top supernatant was removed and the pellet was washed with $70 \%$ alcohol and vacuum dried. The pellet was resuspended with sterile double distilled water. With this aliquot one half volume of 7.5 M Ammonium acetate and 2.5 volume of absolute alcohol was added. The contents were mixed gently and kept for overnight precipitation at $-70^{\circ} \mathrm{C}$. The tubes were centrifuged at 12,000 rpm for $10 \mathrm{~min}$ and the supernatant was removed. The pellet was washed with $70 \%$ alcohol and dried under a vacuum. Finally, the pellet was thoroughly resuspended with $20 \mu \mathrm{L}$ of sterile double-distilled water and $2 \mu \mathrm{L}$ of the sample was used for PCR analysis. 


\subsection{Chop-PCR}

Three Methylation-Sensitive Restriction Enzymes (MSREs) such as Sau3AI, MboI, and HpaII were selected for chop-PCR. The BYVMV viral DNA isolated from the infiltrated plants was quantified by fluorimetry using Hoechst 33258 dye and an equal quantity of viral DNA was digested with MSREs. $300 \mathrm{ng}$ of isolated viral DNA was digested with 10 units of each MSRE with a total volume of $20 \mu \mathrm{L}$ per reaction. For each reaction mixture, buffers specific to the enzyme were used at $1 \times$ final concentration and incubated at $37^{\circ} \mathrm{C}$ for $3 \mathrm{~h}$. For control, the same quantity of DNA was taken without the enzyme. PCR was performed by taking an equal quantity of digested and undigested viral DNA samples as templates with various primers (Table 1 ) and proper controls.

\subsection{Southern Hybridization}

Isolated viral DNA was quantified using a fluorescent Hoechst 33258 dye. $5 \mu \mathrm{g}$ of isolated viral DNA from each plant sample was loaded on $0.8 \%$ agarose gel and electrophoresed at $100 \mathrm{~V}$ in $1 \times$ TNE buffer ( $40 \mathrm{mM}$ Tris-acetate, $\mathrm{pH} 7.5,20 \mathrm{mM}$ sodium acetate and $2 \mathrm{mM}$ EDTA) $[53,54]$. After electrophoresis the gel was treated with $250 \mathrm{~mL}$ of denaturation solution for 30 min under constant shaking. The gel was washed with sterile water and treated with $250 \mathrm{~mL}$ of neutralization solution by keeping it under constant shaking for $30 \mathrm{~min}$; DNA was further transferred on to the Biobond $^{\mathrm{TM}}$ nylon transfer membrane (Sigma-Aldrich, St. Louis, MO, USA) (using 20 $\times$ SSC (Saline Sodium Citrate buffer- $0.3 \mathrm{M} \mathrm{Na}_{3} \mathrm{C}_{6} \mathrm{H}_{5} \mathrm{O}_{7}, 3 \mathrm{M} \mathrm{NaCl} \mathrm{pH}$ 7.0). The hybridization, labeling and detection of nucleic acid was carried out by following the instructions from Alkphos' direct labelling and detection system (GE Healthcare, Buckinghamshire, UK).

\subsection{Quantitative PCR ( $q P C R)$}

Absolute quantification of the viral DNA was done by standard curve method using ABI 7000 sequence detection systems from Applied Biosystems, Foster city, CA, USA. Standards were prepared by using plasmids having a single copy of the viral DNA genome which was used for making serial dilutions from $10^{6}$ to $10^{9}$. The real-time PCR master mix contains $1 \times$ SYBR green mix, target sequence-specific forward and reverse primers at $10 \mathrm{pM}$ concentration, Template DNA (50 ng) and sterile double-distilled(dd) water to make the total volume $20 \mu \mathrm{L}$. PCR cycling parameters include 1 cycle of $50^{\circ} \mathrm{C}$ for $2 \mathrm{~min}, 1$ cycle of $95^{\circ} \mathrm{C}$ for $3 \mathrm{~min}, 40$ cycles each of $95^{\circ} \mathrm{C}$ for $15 \mathrm{~s}$ followed by $60^{\circ} \mathrm{C}$ for $1 \mathrm{~min}$. The viral copy number was determined on the basis of threshold $\mathrm{Ct}$ values. A dissociation curve was chosen for the reaction specificity assessment using target DNA-specific peaks. Three biological samples were taken in triplicates to get consistent values and data were analysed using ABI PRISM 7000 system SDS software (Thermo Scientific, Waltham, MA, USA).

\subsection{Protoplast Isolation and Transfection}

Protoplast isolation and transfection were done by following the Sheen lab protocol [55]. Leaf mesophyll protoplast was isolated from 4-6 weeks old $N$. benthamiana plant leaves by using cellulase onozuka R-10 and Macerozyme R-10. The enzyme solution was prepared by dissolving $1.5 \%$ cellulose R10 $(w / v), 0.4 \%$ Macerozyme R10 $(w / v)$ and $20 \mathrm{mM} \mathrm{KCl}$ in $20 \mathrm{mM}$ MES pH 5.7 . The solution was incubated at $55{ }^{\circ} \mathrm{C}$ for $10 \mathrm{~min}$ to inactivate the DNase, protease and increase the enzyme solubility. The mixture was cooled to $25^{\circ} \mathrm{C}$ and $10 \mathrm{mM} \mathrm{CaCl}_{2}$ and $0.1 \%$ BSA was added and dissolved completely. The final clear and light brown colour enzyme solution was filtered into a clean petridish using a $0.45 \mu \mathrm{m}$ syringe filter. The leaf blade was finely cut into small strips using a sharp blade and the leaf strips were immediately immersed in the enzyme mixture without delay. This setup was kept undisturbed under a vacuum and dark conditions for $3 \mathrm{~h}$. After incubation, the enzyme solution containing the protoplasts was gently swirled and filtered using a fiber mesh. The isolated protoplasts were washed with W5 solution $\left(154 \mathrm{mM} \mathrm{NaCl}, 125 \mathrm{mM} \mathrm{CaCl}_{2}\right.$ and $5 \mathrm{mM} \mathrm{KCl}$ dissolved in $2 \mathrm{mM}$ MES $\mathrm{pH}$ 5.7) and counted using Haemocytometer. The protoplasts were diluted to the desired 
concentration using MMG (0.4M Mannitol, and $15 \mathrm{mM} \mathrm{MgCl}_{2}$ dissolved in $4 \mathrm{mM}$ MES $\mathrm{pH}$ 5.7) solution and $2 \times 10^{5}$ cells were taken for transfection of each plasmid construct.

The PEG-CaCl $2\left(0.2 \mathrm{M}\right.$ mannitol, $100 \mathrm{mM} \mathrm{CaCl}_{2}$ dissolved in $40 \%$ PEG $\left.4000(w / v)\right)$ solution was used for protoplast transfection. The transfection mixture was prepared by adding $7 \mu \mathrm{g}$ of plasmid DNA (various PTR constructs of BYVMV), $2 \times 10^{5}$ protoplasts with a total volume of $100 \mu \mathrm{L}$, $50 \mu \mathrm{g}$ of calf thymus DNA (Carrier DNA) and $110 \mu \mathrm{L}$ of $\mathrm{PEG}-\mathrm{CaCl}_{2}$ solution in a clean $1.5 \mathrm{~mL}$ tube. The transfection mixture was mixed completely by tapping gently and kept undisturbed at $25^{\circ} \mathrm{C}$ for $20 \mathrm{~min}$.After incubation, the mixture was washed with W5 solution and the cells were recovered by centrifugation at $100 \times g$ for $2 \mathrm{~min}$. The pellet containing transfected protoplasts was resuspended in WI solution and incubated for 3 days.After the incubation period, the protoplasts were lysed and total DNA was isolated by $2 \times$ CTAB method. The isolated DNA was treated with $D p n I$ to degrade the initial template arising from the transfection. Further DNA was subjected to chloroform: Isoamyl alcohol wash twice and precipitated with absolute alcohol. The final aliquot was resuspended in $0.1 \times$ TE buffer $\mathrm{pH}$ 8. Absolute quantification of viral DNA was done by standard curve method by taking $50 \mathrm{ng}$ of total DNA from each sample.

\subsection{Bisulfite Conversion}

Bisulfite conversion of viral DNA was performed using an Epitect bisulfite conversion and cleanup kit (Cat. No: 59104, Qiagen, Hilden, Germany). Specific kit buffers were diluted with ethanol as per the manufacturer's recommendations. Since the bisulfite method solely depends on the complete conversion of cytosine and the complete non-conversion of 5-mC, initially, we decided to compare the sensitivity of the method by utilizing different sizes of DNA plasmid and concentration by keeping the kit manufacturer's recommended temperature $\left(60^{\circ} \mathrm{C}\right)$ as constant. Towards achieving an effective conversion rate, we transformed pBlue Script II plasmid containing full-length BYVMV (pBlue DNA A, $5.7 \mathrm{~kb}$ ) or $\beta$ satellite (pBlue $\beta, 4.3 \mathrm{~kb}$ ) into a methylation-deficient E. coli strain ET12567 $\left(d \mathrm{dm}^{-} \mathrm{dam}^{-} h s d \mathrm{M}^{-}\right)$. Various concentrations of plasmids $(0.5,1,2$ and $4 \mu \mathrm{g})$ isolated from ET12567 were subjected to bisulfite conversion without shearing the DNA. The DNA thus converted was subjected to rolling circle amplification (RCA) with the random primers as described earlier [56]. A prominent amplification was found only with 2 or $4 \mu \mathrm{g}$ concentration and the concatemers were submitted for NGS (refer Sections 4.10 and 4.11). The output data was analysed with MethGo software (refer Section 4.11) for graphical representation of the methylation level of different genomic regions of BYVMV; it was concluded that $2 \mu \mathrm{g}$ DNA was optimal for the bisulfite conversion.

The bisulfite reaction components consist of $2 \mu \mathrm{g}$ of the viral DNA sample (with total volume of $20 \mu \mathrm{L}$ ), $85 \mu \mathrm{L}$ of bisulfite mix, $35 \mu \mathrm{L}$ of DNA protect buffer and RNase free water to make the final volume of $140 \mu \mathrm{L}$. The DNA protect buffer was turned from green to blue upon resuspending the DNA-bisulfite mix, which indicated sufficient mixing and the correct $\mathrm{pH}$. For bisulfite conversion, a separate PCR protocol was followed as per the kit manual. The PCR cycle has an alternate cycle of denaturation and incubation which includes $5 \mathrm{~min}$ at $95^{\circ} \mathrm{C}, 25 \mathrm{~min}$ at $60{ }^{\circ} \mathrm{C}, 5 \mathrm{~min}$ at $95{ }^{\circ} \mathrm{C}, 85 \mathrm{~min}$ at $60^{\circ} \mathrm{C}, 5 \mathrm{~min}$ at $95^{\circ} \mathrm{C}, 175 \mathrm{~min}$ at $60^{\circ} \mathrm{C}$ and an indefinite hold at $20^{\circ} \mathrm{C}$. The DNA clean-up steps were performed by following the protocol from the kit manual using DNA extraction columns and buffers given with the kit. Following conversion, desulphonation and washing steps, the final aliquot of DNA was eluted using an elution buffer with a total volume of $20 \mu \mathrm{L}$ and then immediately used for RCA [56].

The methylation-deficient E. coli strain ET12567 $\left(\mathrm{dam}^{-} d \mathrm{dm}^{-} h s d \mathrm{M}^{-}\right)$was used to get the unmethylated control DNA for the bisulfite experiment. Further, a plasmid containing the full length genome of $\beta$ satellite was transformed to ET12567 and the transformant colonies were selected on suitable antibiotic agar media. The $\beta$ satellite plasmid isolated from the ET12567 was confirmed by restriction digestion and used as unmethylated DNA control. The control DNA was processed as similar to the test sample for Bisulfite conversion and RCA. The RCA product proceeded for NGS. 


\section{9. $R C A$}

RCA was performed in vitro using $\phi 29$ DNA polymerase which can amplify the bisulfite converted viral DNA. The reaction mix contained $1 \times \phi 29$ DNA polymerase reaction Buffer, $1 \mathrm{mM}$ dNTP mix, $50 \mu \mathrm{M}$ Exo-resistant random primers and $50 \mathrm{ng}$ of template DNA. The mixture was mixed gently and the total volume was made to $20 \mu \mathrm{L}$ with nuclease free water. The template was denatured at $95{ }^{\circ} \mathrm{C}$ for $3 \mathrm{~min}$ and then cooled to room temperature. As soon as the mixture cooled, 5 units of $\phi 29$ DNA polymerase (Thermo Scientific, Waltham, MA, USA) and 0.02 units of pyrophosphatase (Thermo Scientific, Waltham, MA, USA) were added and incubated at $30^{\circ} \mathrm{C}$ for $72 \mathrm{~h}$. Finally, the enzyme was inactivated by incubating the reaction mix at $65^{\circ} \mathrm{C}$ for $10 \mathrm{~min}$. DNA amplification was confirmed on $0.8 \%$ agarose gel.

\subsection{DNA Processing for Illumina Sequencing and Library Preparation}

The RCA product was directly used as a template for Illumina sequencing to get the reads of bisulfite converted BYVMV viral DNA sequences [57]. For Illumina sequencing, $200 \mathrm{ng}$ of DNA was sheared using Covaris S2 sonicator (Covaris, Woburn, MA, USA). This process generated 150 bp long DNA fragments and the fragment size distribution was checked on Agilent 2200 tape station with D1000 DNA screen tapes and reagents (Agilent Technologies, Santa Clara, CA, USA) and purified using high prep magnetic beads (Magbio Genomics, Gaithersburg, MD, USA). The purified fragments were end repaired, adenylated and ligated to Illumina multiplex barcode adapters, as per the kit protocol. Illumina Universal adapter (5'-AATGATACGGCGACCACCGAGATCTACACTCTTTCCCTACACGACGCTCTTCCGATCT-3') and Index Adapter (5'-GATCGGAAGAGCACACGTCTGAACTCCAGTCAC [INDEX]ATCTCGTAT GCCGTCTTCTGCTTG-3' [INDEX]) were used in this study. The adapter-ligated DNA was purified and amplified for 6 cycles of PCR using Illumina-compatible primers. The final PCR product was purified with high prep beads followed by primary quality control check. The Illumina-compatible sequencing library was initially quantified by Qubit fluorimeter (Thermo Scientific, Waltham, MA, USA) and its fragment distribution was analysed on Agilent 2200 Tape station.

\subsection{Mapping Cytosine Methylation Using MethGo}

MethGo is Python-based software designed for the analysis of data from whole genome bisulfite sequencing (WGBS) and reduced representation of bisulfite sequencing (RRBS) [28]. Prior to MethGo analysis, the WGBS reads should be proceeded for the removal of adapter sequences using trimmomatic software and aligned to the reference genome using BS-Seeker2. BS-Seeker2 performs genome editing, mapping bisulfite sequence reads against the given reference genome and calling methylation levels expeditiously [58]. We used MethGo and BS-Seeker2 for the analysis of DNA methylation by following the default settings. Coverage of methylation sites is a criterion for assessing the quality of methylation data. The COV module of MethGo software extracts the coverage for each cytosine from the BS-Seeker alignment file and generates a reverse cumulative plot for methylation sites in CG, CHG and CHH context (where $\mathrm{H}$ refers to A, C or T). The quality of NGS data can be easily evaluated by analysing the percentage of methylation sites covered and the depth of coverage $(x)$. Methylation sites with high coverage is likely to provide accurate methylation status. The $y$-axis of the coverage map represents the percentage of methylation sites covered in the given genome from 0 to 100 and the $x$-axis represents the depth of coverage $(x)$. The raw data resulting from BYVMV bisulfite NGS was deposited in NCBI Sequence Read Archive (SRA) with Bioproject reference number: PRJNA428793 (SRP128162).

Supplementary Materials: The following are available online at http:/ /www.mdpi.com/2075-4655/2/2/7/s1.

Author Contributions: G.P., K.S.D.B. and A.G. conceived and designed experiments. K.S.D.B., A.G., J.K., K.K., P.S., S.A.C. and J.T. performed experiments. Data analysis was done by K.S.D.B., N.S., A.G. and G.P. Paper written by K.S.D.B., G.P., A.D.B. and A.G.

Acknowledgments: We thank Department of Science and Technology (DST), Government of India, New Delhi for giving INSPIRE fellowship to K.S.D.B. (Ref No: IF110735). Support from DBT (Ref: No. BT/PR2061/AGR/36/707/2011 
dated 25-06-2013), SERB (Ref: No. SB/EMEQ-070/2013 dated 05-07-2013), DST-PURSE and UGC-SAP is greatly appreciated for the equipment grant. We express our gratitude to K. Veluthambi, and Sridevi from the School of Biotechnology, Madurai Kamaraj University for their valuable suggestions and lab facilities.

Conflicts of Interest: The authors declare no conflict of interest.

\section{References}

1. Varsani, A.; Roumagnac, P.; Fuchs, M.; Navas-Castillo, J.; Moriones, E.; Idris, A.; Briddon, R.W.; Rivera-Bustamante, R.; Murilo Zerbini, F.; Martin, D.P. Capulavirus and Grablovirus: Two new genera in the family Geminiviridae. Arch. Virol. 2017, 162, 1819-1831. [CrossRef] [PubMed]

2. Brown, J.K.; Zerbini, F.M.; Navas-Castillo, J.; Moriones, E.; Ramos-Sobrinho, R.; Silva, J.C.F.; Fiallo-Olivé, E.; Briddon, R.W.; Hernández-Zepeda, C.; Idris, A.; et al. Revision of Begomovirus taxonomy based on pairwise sequence comparisons. Arch. Virol. 2015, 160, 1593-1619. [CrossRef] [PubMed]

3. Hanley-Bowdoin, L.; Bejarano, E.R.; Robertson, D.; Mansoor, S. Geminiviruses: Masters at redirecting and reprogramming plant processes. Nat. Rev. Microbiol. 2013, 11, 777-788. [CrossRef] [PubMed]

4. Schneider, R.J.; Mohr, I. Translation initiation and viral tricks. Trends Biochem. Sci. 2003, 28, 130-136. [CrossRef]

5. Pilartz, M.; Jeske, H. Mapping of abutilon mosaic geminivirus minichromosomes. J. Virol. 2003, 77, 10808-10818. [CrossRef] [PubMed]

6. Velayudha Vimala Kumar, K.; Srikakulam, N.; Padbhanabhan, P.; Pandi, G. Deciphering microRNAs and Their Associated Hairpin Precursors in a Non-Model Plant, Abelmoschus esculentus. Non Coding RNA 2017, 3, 19. [CrossRef] [PubMed]

7. Raja, P.; Sanville, B.C.; Buchmann, R.C.; Bisaro, D.M. Viral Genome Methylation as an Epigenetic Defense against Geminiviruses. J. Virol. 2008, 82, 8997-9007. [CrossRef] [PubMed]

8. Ermak, G.; Paszkowski, U.; Wohlmuth, M.; Scheid, O.M.; Paszkowski, J. Cytosine methylation inhibits replication of African cassava mosaic virus by two distinct mechanisms. Nucleic Acids Res. 1993, 21, 3445-3450. [CrossRef] [PubMed]

9. Raja, P.; Wolf, J.N.; Bisaro, D.M. RNA silencing directed against geminiviruses: Post-transcriptional and epigenetic components. Biochim. Biophys. Acta BBA Gene Regul. Mech. 2010, 1799, 337-351. [CrossRef] [PubMed]

10. Ashapkin, V.V.; Kutueva, L.I.; Vanyushin, B.F. Plant DNA Methyltransferase Genes: Multiplicity, Expression, Methylation Patterns. Biochem. Biokhimiia 2016, 81, 141-151. [CrossRef] [PubMed]

11. Mitsudome, T.; Mon, H.; Xu, J.; Li, Z.; Lee, J.M.; Patil, A.A.; Masuda, A.; Iiyama, K.; Morokuma, D.; Kusakabe, T. Biochemical characterization of maintenance DNA methyltransferase DNMT-1 from silkworm, Bombyx mori. Insect Biochem. Mol. Biol. 2015, 58, 55-65. [CrossRef] [PubMed]

12. Pavlopoulou, A.; Kossida, S. Plant cytosine-5 DNA methyltransferases: Structure, function, and molecular evolution. Genomics 2007, 90, 530-541. [CrossRef] [PubMed]

13. Hashimshony, T.; Zhang, J.; Keshet, I.; Bustin, M.; Cedar, H. The role of DNA methylation in setting up chromatin structure during development. Nat. Genet. 2003, 34, 187-192. [CrossRef] [PubMed]

14. Severin, P.M.D.; Zou, X.; Gaub, H.E.; Schulten, K. Cytosine methylation alters DNA mechanical properties. Nucleic Acids Res. 2011, 39, 8740-8751. [CrossRef] [PubMed]

15. Bisaro, D.M. Silencing suppression by geminivirus proteins. Virology 2006, 344, 158-168. [CrossRef] [PubMed]

16. Rodríguez-Negrete, E.; Lozano-Durán, R.; Piedra-Aguilera, A.; Cruzado, L.; Bejarano, E.R.; Castillo, A.G. Geminivirus Rep protein interferes with the plant DNA methylation machinery and suppresses transcriptional gene silencing. New Phytol. 2013, 199, 464-475. [CrossRef] [PubMed]

17. Wang, B.; Li, F.; Huang, C.; Yang, X.; Qian, Y.; Xie, Y.; Zhou, X. V2 of tomato yellow leaf curl virus can suppress methylation-mediated transcriptional gene silencing in plants. J. Gen. Virol. 2014, 95, 225-230. [CrossRef] [PubMed]

18. Yang, X.; Xie, Y.; Raja, P.; Li, S.; Wolf, J.N.; Shen, Q.; Bisaro, D.M.; Zhou, X. Suppression of methylation-mediated transcriptional gene silencing by $\beta C 1-S A H H$ protein interaction during geminivirus- $\beta$ satellite infection. PLoS Pathog. 2011, 7, e1002329. [CrossRef] [PubMed]

19. Jose, J.; Usha, R. Bhendi yellow vein mosaic disease in India is caused by association of a DNA $\beta$ satellite with a begomovirus. Virology 2003, 305, 310-317. [CrossRef] [PubMed] 
20. Priyavathi, P.; Kavitha, V.; Gopal, P. Complex Nature of Infection Associated with Yellow Vein Mosaic Disease in Bhendi (Abelmoschus esculentus). Curr. Sci. 2016, 111, 1511-1515. [CrossRef]

21. Chandran, S.A.; Levy, Y.; Mett, A.; Belausov, E.; Ramakrishnan, U.; Gafni, Y. Mapping of functional region conferring nuclear localization and karyopherin $\alpha$-binding activity of the C2 protein of bhendi yellow vein mosaic virus. J. Gen. Virol. 2012, 93, 1367-1374. [CrossRef] [PubMed]

22. Gopal, P.; Pravin Kumar, P.; Sinilal, B.; Jose, J.; Kasin Yadunandam, A.; Usha, R. Differential roles of C4 and $\beta C 1$ in mediating suppression of post-transcriptional gene silencing: Evidence for transactivation by the C2 of Bhendi yellow vein mosaic virus, a monopartite begomovirus. Virus Res. 2007, 123, 9-18. [CrossRef] [PubMed]

23. Chandran, S.A.; Jeyabharathy, C.; Usha, R. The C2 protein of Bhendi yellow vein mosaic virus plays an important role in symptom determination and virus replication. Virus Genes 2014, 48, 203-207. [CrossRef] [PubMed]

24. Rigden, J.E.; Krake, L.R.; Rezaian, M.A.; Dry, I.B. ORF C4 of tomato leaf curl geminivirus is a determinant of symptom severity. Virology 1994, 204, 847-850. [CrossRef] [PubMed]

25. Shen, Q.; Liu, Z.; Song, F.; Xie, Q.; Hanley-Bowdoin, L.; Zhou, X. Tomato SISnRK1 protein interacts with and phosphorylates $\beta C 1$, a pathogenesis protein encoded by a geminivirus $\beta$-satellite. Plant Physiol. 2011, 157, 1394-1406. [CrossRef] [PubMed]

26. Saeed, M.; Behjatnia, S.A.A.; Mansoor, S.; Zafar, Y.; Hasnain, S.; Rezaian, M.A. A single complementary-sense transcript of a geminiviral DNA $\beta$ satellite is determinant of pathogenicity. Mol. Plant Microbe Interact. MPMI 2005, 18, 7-14. [CrossRef] [PubMed]

27. Yang, J.-Y.; Iwasaki, M.; Machida, C.; Machida, Y.; Zhou, X.; Chua, N.-H. $\beta C 1$, the pathogenicity factor of TYLCCNV, interacts with AS1 to alter leaf development and suppress selective jasmonic acid responses. Genes Dev. 2008, 22, 2564-2577. [CrossRef] [PubMed]

28. Liao, W.-W.; Yen, M.-R.; Ju, E.; Hsu, F.-M.; Lam, L.; Chen, P.-Y. MethGo: A comprehensive tool for analyzing whole-genome bisulfite sequencing data. BMC Genom. 2015, 16 (Suppl. 12), S11. [CrossRef] [PubMed]

29. Xie, Y.; Zhao, L.; Jiao, X.; Jiang, T.; Gong, H.; Wang, B.; Briddon, R.W.; Zhou, X. A recombinant begomovirus resulting from exchange of the C4 gene. J. Gen. Virol. 2013, 94, 1896-1907. [CrossRef] [PubMed]

30. Vanitharani, R.; Chellappan, P.; Pita, J.S.; Fauquet, C.M. Differential roles of AC2 and AC4 of cassava geminiviruses in mediating synergism and suppression of posttranscriptional gene silencing. J. Virol. 2004, 78, 9487-9498. [CrossRef] [PubMed]

31. Llave, C.; Kasschau, K.D.; Carrington, J.C. Virus-encoded suppressor of posttranscriptional gene silencing targets a maintenance step in the silencing pathway. Proc. Natl. Acad. Sci. USA 2000, 97, 13401-13406. [CrossRef] [PubMed]

32. Vanitharani, R.; Chellappan, P.; Fauquet, C.M. Geminiviruses and RNA silencing. Trends Plant Sci. 2005, 10, 144-151. [CrossRef] [PubMed]

33. Wang, X.-B.; Wu, Q.; Ito, T.; Cillo, F.; Li, W.-X.; Chen, X.; Yu, J.-L.; Ding, S.-W. RNAi-mediated viral immunity requires amplification of virus-derived siRNAs in Arabidopsis thaliana. Proc. Natl. Acad. Sci. USA 2010, 107, 484-489. [CrossRef] [PubMed]

34. Wang, H.; Hao, L.; Shung, C.-Y.; Sunter, G.; Bisaro, D.M. Adenosine Kinase Is Inactivated by Geminivirus AL2 and L2 Proteins. Plant Cell 2003, 15, 3020-3032. [CrossRef] [PubMed]

35. Zhang, Z.; Chen, H.; Huang, X.; Xia, R.; Zhao, Q.; Lai, J.; Teng, K.; Li, Y.; Liang, L.; Du, Q.; et al. BSCTV C2 Attenuates the Degradation of SAMDC1 to Suppress DNA Methylation-Mediated Gene Silencing in Arabidopsis. Plant Cell Online 2011, 23, 273-288. [CrossRef] [PubMed]

36. Cui, X.; Zhou, X. AC2 and AC4 proteins of Tomato yellow leaf curl China virus and Tobacco curly shoot virus mediate suppression of RNA silencing. Chin. Sci. Bull. 2004, 49, 2607-2612. [CrossRef]

37. Stanley, J.; Latham, J.R.; Pinner, M.S.; Bedford, I.; Markham, P.G. Mutational analysis of the monopartite geminivirus beet curly top virus. Virology 1992, 191, 396-405. [CrossRef]

38. Jupin, I.; De Kouchkovsky, F.; Jouanneau, F.; Gronenborn, B. Movement of tomato yellow leaf curl geminivirus (TYLCV): Involvement of the protein encoded by ORF C4. Virology 1994, 204, 82-90. [CrossRef] [PubMed]

39. Krake, L.R.; Rezaian, M.A.; Dry, I.B. Expression of the Tomato Leaf Curl Geminivirus C4 Gene Produces Viruslike Symptoms in Transgenic Plants. Mol. Plant. Microbe Interact. 1998, 11, 413-417. [CrossRef] 
40. Latham, J.R.; Saunders, K.; Pinner, M.S.; Stanley, J. Induction of plant cell division by beet curly top virus gene C4. Plant J. 1997, 11, 1273-1283. [CrossRef]

41. Krichevsky, A.; Kozlovsky, S.V.; Gafni, Y.; Citovsky, V. Nuclear import and export of plant virus proteins and genomes. Mol. Plant Pathol. 2006, 7, 131-146. [CrossRef] [PubMed]

42. Kunik, T.; Palanichelvam, K.; Czosnek, H.; Citovsky, V.; Gafni, Y. Nuclear import of the capsid protein of tomato yellow leaf curl virus (TYLCV) in plant and insect cells. Plant J. Cell Mol. Biol. 1998, 13, 393-399. [CrossRef]

43. Palanichelvam, K.; Kunik, T.; Citovsky, V.; Gafni, Y. The capsid protein of tomato yellow leaf curl virus binds cooperatively to single-stranded DNA. J. Gen. Virol. 1998, 79 Pt 11, 2829-2833. [CrossRef] [PubMed]

44. Usha, R.; Zrachya, A.; Levy, Y.; Spanov, H.; Gafni, Y. Protein-protein interactions and nuclear trafficking of coat protein and $\beta C 1$ protein associated with Bhendi yellow vein mosaic disease. Virus Res. 2006, 122, 127-136. [CrossRef]

45. Guha, D.; Poornima Priyadarshini, C.G.; Purakayastha, A.; Thippeswamy, R.; Lakshmikanth, M.; Savithri, H.S. Biochemical characterization of C4 protein of Cotton leaf curl Kokhran Virus-Dabawali. Biochim. Biophys. Acta 2013, 1830, 3734-3744. [CrossRef] [PubMed]

46. Rojas, M.R.; Jiang, H.; Salati, R.; Xoconostle-Cázares, B.; Sudarshana, M.R.; Lucas, W.J.; Gilbertson, R.L. Functional analysis of proteins involved in movement of the monopartite begomovirus, Tomato yellow leaf curl virus. Virology 2001, 291, 110-125. [CrossRef] [PubMed]

47. Buchmann, R.C.; Asad, S.; Wolf, J.N.; Mohannath, G.; Bisaro, D.M. Geminivirus AL2 and L2 proteins suppress transcriptional gene silencing and cause genome-wide reductions in cytosine methylation. J. Virol. 2009, 83, 5005-5013. [CrossRef] [PubMed]

48. Wang, H.; Buckley, K.J.; Yang, X.; Buchmann, R.C.; Bisaro, D.M. Adenosine kinase inhibition and suppression of RNA silencing by geminivirus AL2 and L2 proteins. J. Virol. 2005, 79, 7410-7418. [CrossRef] [PubMed]

49. Li, F.; Huang, C.; Li, Z.; Zhou, X. Suppression of RNA Silencing by a Plant DNA Virus Satellite Requires a Host Calmodulin-Like Protein to Repress RDR6 Expression. PLoS Pathog. 2014, 10, e1003921. [CrossRef] [PubMed]

50. Vieira, J.; Messing, J. New pUC-derived cloning vectors with different selectable markers and DNA replication origins. Gene 1991, 100, 189-194. [PubMed]

51. Ditta, G.; Stanfield, S.; Corbin, D.; Helinski, D.R. Broad host range DNA cloning system for gram-negative bacteria: Construction of a gene bank of Rhizobium meliloti. Proc. Natl. Acad. Sci. USA 1980, 77, 7347-7351. [CrossRef] [PubMed]

52. Jose, J.; Usha, R. Extraction of geminiviral DNA from a highly mucilaginous plant (Abelmoschus esculentus). Plant Mol. Biol. Rep. 2000, 18, 349-355. [CrossRef]

53. Hong, Y. Virus Resistance in Nicotiana benthamiana Conferred by African Cassava Mosaic Virus Replication-Associated Protein (ACI) Transgene. Mol. Plant. Microbe Interact. 1996, 9, 219-255. [CrossRef]

54. Karthikeyan, C.; Patil, B.L.; Borah, B.K.; Resmi, T.R.; Turco, S.; Pooggin, M.M.; Hohn, T.; Veluthambi, K. Emergence of a Latent Indian Cassava Mosaic Virus from Cassava Which Recovered from Infection by a Non-Persistent Sri Lankan Cassava Mosaic Virus. Viruses 2016, 8, 264. [CrossRef] [PubMed]

55. Yoo, S.-D.; Cho, Y.-H.; Sheen, J. Arabidopsis mesophyll protoplasts: A versatile cell system for transient gene expression analysis. Nat. Protoc. 2007, 2, 1565-1572. [CrossRef] [PubMed]

56. Paprotka, T.; Deuschle, K.; Metzler, V.; Jeske, H. Conformation-Selective Methylation of Geminivirus DNA. J. Virol. 2011, 85, 12001-12012. [CrossRef] [PubMed]

57. Deuschle, K.; Kepp, G.; Jeske, H. Differential methylation of the circular DNA in geminiviral minichromosomes. Virology 2016, 499, 243-258. [CrossRef] [PubMed]

58. Guo, W.; Fiziev, P.; Yan, W.; Cokus, S.; Sun, X.; Zhang, M.Q.; Chen, P.-Y.; Pellegrini, M. BS-Seeker2: A versatile aligning pipeline for bisulfite sequencing data. BMC Genom. 2013, 14, 774. [CrossRef] [PubMed]

(C) 2018 by the authors. Licensee MDPI, Basel, Switzerland. This article is an open access article distributed under the terms and conditions of the Creative Commons Attribution (CC BY) license (http:// creativecommons.org/licenses/by/4.0/). 